Universidade de Brasília

Centro de Excelência em Turismo

\title{
EVOLUÇÃO DO ECOTURISMO NO BRASIL: DE 1993 A 2003
}

Celecina Barros da Silva Correia

Lúcio Carlos de Carvalho Santos

Monografia apresentada ao Centro de Excelência em Turismo da Universidade de Brasília como requisito parcial para a obtenção do certificado de Especialista em Ecoturismo.

Brasília, DF, maio de 2003. 
UNIVERSIDADE DE BRASÍLIA

Centro de Excelência em Turismo

Curso de Especialização em Ecoturismo

\title{
EVOLUÇÃO DO ECOTURISMO NO BRASIL: DE 1993 À 2003
}

Celecina Barros da Silva Correia

\author{
Banca Examinadora
}

Lúcio Carlos de Carvalho Santos, MSC

Orientador

\author{
Dóris Santos de Faria, Dra \\ Membro da Banca
}

Brasília, DF, 26 de maio de 2003 
RESUMO

O processo de desenvolvimento humano sempre necessitou da utilização dos recursos naturais. Com a revolução industrial e o aumento populacional, os usos excessivos dos recursos naturais aumentaram, sem a preocupação com os prejuízos oriundos dessa prática, o que refletiu na degradação do meio ambiente. A partir dos anos 60 , as preocupações acerca dos problemas ambientais aumentaram, com a constatação de que a preservação do meio ambiente era necessária para a sobrevivência humana.

Nesta monografia abordaremos a evolução do ecoturismo bem como a sua contribuição para o mercado de trabalho, destacando a possibilidade de consolidá-lo como uma alternativa para promover o desenvolvimento sustentável, informando a comunidade envolvida da importância da preservação do meio ambiente. 
ABSTRACT

The human development process allways needed natural resources. With the advent of the industrtial revolution and the population explosion, the excessive use of natural resources incresead and there was no care about the losses caused by this practice, which cause the environment degradation. In the beginning of the 60's, the worries concerning environmental problems incresed and people start to realize that the environment preservation was necessary for human survival.

In this work we will deal with ecoturism evolution as well as its contribution for job market, highlighting the possibitily of consolidate as na alternativa to promote the self-support development, informing the comunity envolved in this type of work of the importancy of ennvironment preservation. 
SUMÁRIO

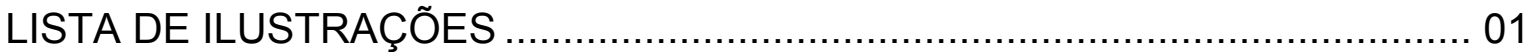

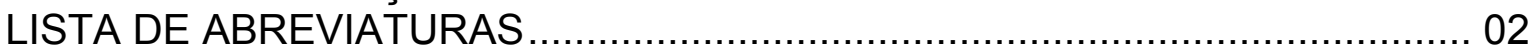

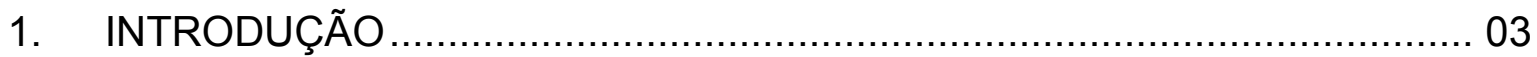

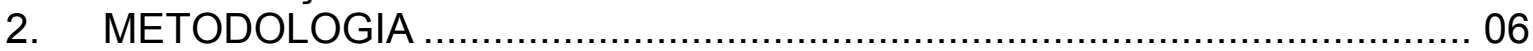

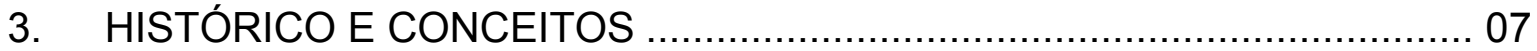

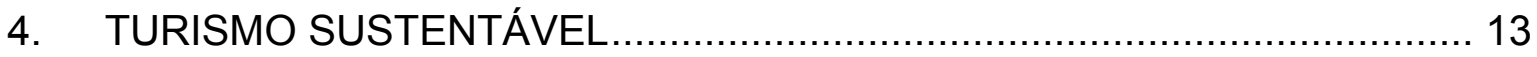

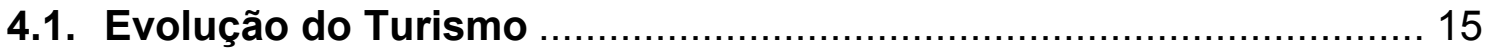

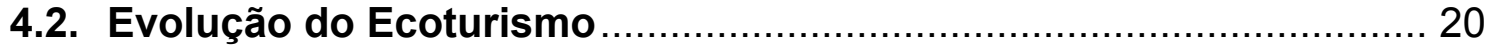

4.3. Turismo Ecológico versus Ecoturismo ......................................... 24

4.4. Ecoturismo no Brasil .............................................................. 25

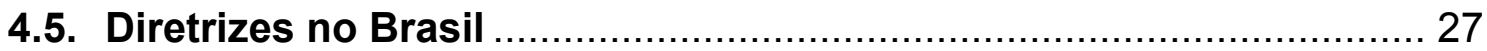

4.6. A Criação de Produtos e Destinos ........................................... 29

4.7. Tendências do Ecoturismo ........................................................ 30

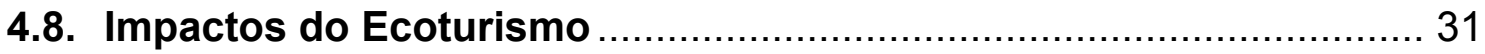

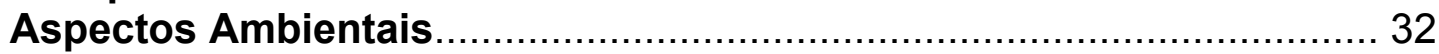

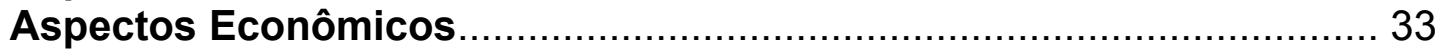

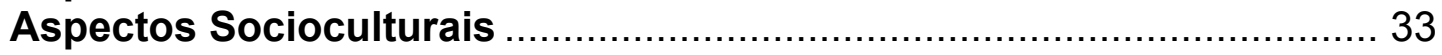

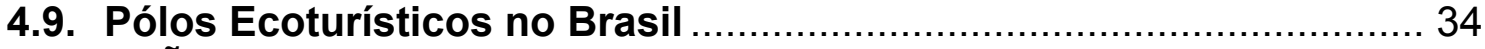

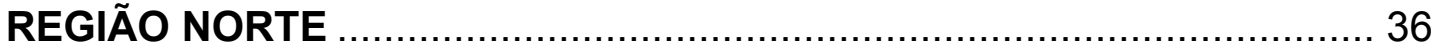

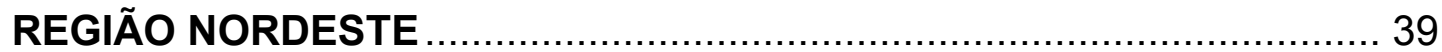

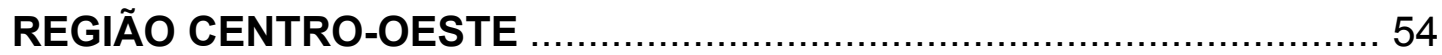

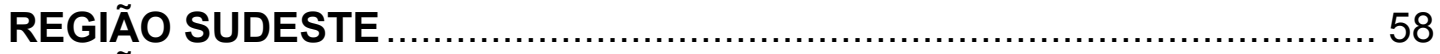

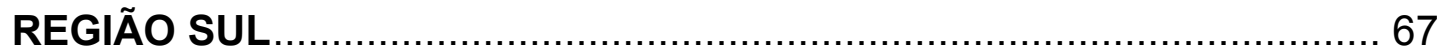

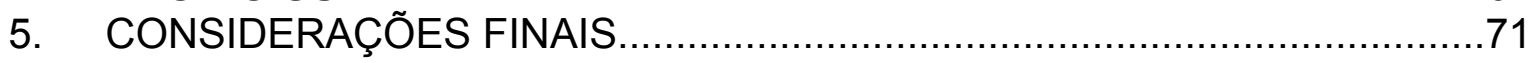

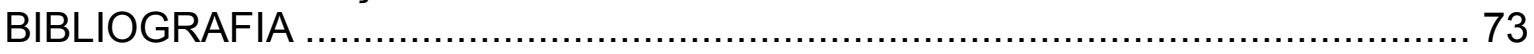




\section{LISTA DE ILUSTRAÇÕES}

Figura 1: Mapa dos Pólos de Ecoturismo.............................................. 37

Figura 2: Pólos de Ecoturismo da Região Norte. ......................................... 40

Figura 3: Pólos de Ecoturismo da Região Nordeste...................................... 42

Figura 4: Pólos de Ecoturismo da Região Centro-Oeste................................... 59

Figura 5: Pólos de Ecoturismo da Região Sudeste ........................................ 61

Figura 6: Pólos de Ecoturismo da Região Sul ................................................ 71 


\section{LISTA DE ABREVIATURAS}

CMMAD - Comissão Mundial sobre Meio Ambiente e Desenvolvimento BNDS - Banco Nacional de Desenvolvimento

EMBRATUR - Instituto Brasileiro de Turismo

IPHAN - Instituto do Patrimônio Histórico e Artístico Nacional

OMT - Organização Mundial do Turismo

ONG's - Organização Não Governamental

UNESCO - Unided Nations Educational, Scientific And Cultural Organization. 


\section{INTRODUÇÃO}

A questão ambiental não envolve apenas a natureza, ela inclui também o direito humano de dispor de qualidade de vida. Com a Revolução Industrial, que levou a economia a transformações econômicas e sociais através dos avanços tecnológicos, os recursos naturais foram utilizados em larga escala causando danos ao meio ambiente. Constatou-se, que era necessário um novo modelo de desenvolvimento que visasse uma política global de sustentabilidade, em que a conservação do meio ambiente estivesse intimamente relacionada com a eficiência econômica e a justiça social. Ou seja, um desenvolvimento que associasse a proteção ambiental às políticas de desenvolvimento, diferente do desenvolvimento predatório vigente até então. A este se denominou modelo sustentável.

No plano internacional, o turismo é uma das atividades econômicas de maior importância. O mercado turístico tem como seus principais agentes econômicos os consumidores que objetivam maximizar suas satisfações e as empresas que buscam maximizar seus lucros. A origem do turismo é antiga, mas o turismo moderno tem sua origem após a Revolução Industrial. No passado era encarado como uma atividade de viagem, mas hoje é uma atividade socioeconômica, pois gera a produção de bens e serviços, sendo uma atividade descentralizada que pode ser organizada em cada município ou região, podendo gerar divisas, criar empregos, distribuir renda, aumentando a qualidade de vida da população.

O turismo é um sistema integrado, sem conscientização ele tornase predatório. Por isso é necessário um planejamento que vise uma definição dos objetivos, um inventário dos recursos naturais e culturais, análise da situação, com planos de longo prazo e projetos estratégicos. Já o ecoturismo é o segmento do turismo que possibilita ao mesmo tempo a eficácia e eficiência na atividade econômica mantendo a diversidade e estabilidade do meio ambiente, tendo como base o novo modelo desejado, podendo atuar como instrumento de 
sensibilização, orientação e equilíbrio entre os desgastes causados pelo desenvolvimento econômico e a necessidade de preservar nosso patrimônio natural e cultural.

O ecoturismo é o segmento do turismo, que tem nos seus princípios o conceito de desenvolvimento sustentável, visando a conservação do meio ambiente via o turismo, além de buscar uma consciência ambientalista, a satisfação e valorização das populações envolvidas.

O Ecoturismo não pode ser considerado uma atividade ideal, não impactante e não poluente, mas se comparado à outras atividades é menos doloso. Entretanto, pode ser praticado de maneira racional, duradoura e capaz de melhorar a qualidade de vida de uma grande parcela da população. É o Ecoturismo responsável, que se aproxima da sustentabilidade, visando a conservação do patrimônio natural e cultural, desenvolvendo atividades lucrativas que possam garantir a sua manutenção e a melhoria de vida das comunidades envolvidas.

Em função de sua estrutura, complexidade e heterogeneidade, a oferta turística resulta na composição de um conjunto de atividades, tanto econômicas como sociais e culturais. Ela compreende os atrativos em geral como recursos naturais, históricos e culturais; infra-estrutura em geral como meios de hospedagem; alimentação; transportes; entretenimento; serviços de apoio ao turista; e outros. É a quantidade de bens e serviços consumidos pelos visitantes que caracteriza a demanda turística. Além da qualidade das destinações turística e da infra-estrutura oferecida ao visitante, a originalidade do lugar é freqüentemente avaliada. A essência do ecoturismo está em oferecer ao turista uma experiência rica e autêntica de vivência junto aos ecossistemas. Associados a isso são propiciados condições de conforto, aconchego, recreação, disponibilidade de equipamentos turísticos característicos e diferenciados, além do importante incentivo às práticas conservacionistas.

O ecoturismo tem demonstrado ser um dos mais eficientes instrumentos econômicos adotados por governos e setores da sociedade comprometidos com o meio ambiente para financiar e garantir a proteção permanente de ecossistemas naturais. A essência do produto ecoturístico é a 
interpretação do ambiente baseada em informações de qualidade, onde se privilegia o interesse do turista pela natureza e pela cultura da região que está sendo visitada. Esse conhecimento abrange muitas áreas como turismo, sociologia, educação ambiental e ecologia. Entretanto, um dos maiores desafios do ecoturismo nacional é ter disponibilidade de pessoal devidamente treinado e capacitado.

O trabalho objetiva dispor o conceito de desenvolvimento sustentável, referente a relação turismo e meio ambiente, mostrando a evolução e a importância do ecoturismo para o Brasil, possibilitando valorizar, preservar o patrimônio, viabilizando retornos econômicos e proporcionando uma educação ambiental através da conscientização da importância da preservação do meio ambiente, além de gerar benefícios para comunidade.

No contexto brasileiro, conciliar a proteção dos recursos naturais com o desenvolvimento, proporcionando benefício às populações e gerando lucros para os empreendedores através do ecoturismo traz desafios específicos. As áreas mais procuradas para este tipo de atividade estão em regiões com grande concentração de pobreza, onde a capacidade de investimentos é pequena. Os passeios "ecológicos" aumentaram, só que num ritmo maior do que as estruturas locais podem atender. O resultado é o surgimento de grande quantidade de serviços turísticos de má qualidade, marcados pela falta de planejamento e treinamento. 


\section{METODOLOGIA}

Este Projeto é fundamentado em uma pesquisa exploratória realizada nos contextos econômico e socioambiental, no qual irá se desenvolver o Ecoturismo no Brasil.

Tendo como base a abordagem qualitativa, comparativa e conceitual de diversos autores, será realizada com o objetivo de registrar e sistematizar os dados coletados, possibilitando, desta forma, uma aproximação maior da realidade do Turismo e do Ecoturismo e da investigação das questões relacionadas ao assunto.

Nesta pesquisa obtiveram-se os dados descritos sobre os lugares e processos interativos através de leituras e pesquisas em bibliotecas e documentos, como: livros, artigos, estudos teóricos, revistas científicas e publicações governamentais do IBAMA, BNDES, EMBRATUR e Ministério do Meio Ambiente.

Procurou-se "compreender os fenômenos segundo as perspectivas dos sujeitos, ou seja, dos participantes da situação do estudo", (Godoy, 1995). 


\section{HISTÓRICO E CONCEITOS}

A modalidade de turismo denominada turismo ecológico, e o ecoturismo, constitui-se num dos alicerces na tentativa de alcançar um modelo sustentável de desenvolvimento. Por ecoturismo podemos entender que ele é uma "viajem responsável a áreas naturais, visando preservar o meio ambiente e promover o bem-estar da população local" (WESTERN, 1999). É um fenômeno característico do final do século XX, e ao que se percebe do século XXI.

O século XX vislumbrou a evolução do ecoturismo além da significativa mudança das excursões às áreas naturais.

Para que o turismo se desenvolva de maneira que se preserve sua atratibilidade, ou seja, que ao longo do tempo, seus atrativos continuem intactos e motivando a vinda de turistas, é necessário muito cuidado no planejamento. Para isso, deve ser elaborado um detalhado Plano de Desenvolvimento Turístico, que é entendido como uma ordenação das "ações do homem sobre o território e ocupar-se em direcionar a construção de equipamentos e facilidades de forma adequada evitando, dessa forma, os efeitos negativos nos recursos, que os destroem ou reduzem sua atratividade" (RUSCHMANN, 1997). Nele deve constar o potencial da área a ser trabalhada, o nível de turismo desejado, a normatização da atividade e as maneiras de se chegar aos objetivos.

Definido inicialmente como "encontro do homem com a natureza em seu estado selvagem", o ecoturismo teve seu conceito ampliado para "modalidade turística que tem como motivação principal viajar para as áreas naturais, pouco modificadas e livres de contaminação, com o objetivo específico de estudar, admirar e desfrutar ativamente de suas paisagens, plantas e animais silvestres, assim como das manifestações culturais existentes nessas áreas" (Ceballos-Lascuráin,95).

O ecoturismo é um dos negócios de ponta do setor de lazer dos últimos anos. É também uma alternativa para o desenvolvimento sustentável em 
determinados casos. Trata-se de uma atividade relativamente nova. O próprio conceito de ecoturismo é provável que seja da década de setenta. Uma das primeiras estratégias de ação em turismo e sustentabilidade surgiu em 1990, com a Conferencia Globo 90, na Columbia Britânica no Canadá, que foi a primeira conferência que reuniu integrantes do ramo do turismo, governos, acadêmicos e ONG's para discutir os efeitos degradantes da indústria do turismo sobre o meio ambiente, e as possibilidades de um turismo ambientalmente sustentável.

Durante a década de oitenta, e dentro de uma filosofia ambientalista ou ecologista, o turismo como atividade econômica foi amplamente criticado. Por se tratar de uma indústria que, embora sem chaminés, criava enormes edificações, como os hotéis à beira do mar, trazendo conseqüências irreversíveis tanto para a população local quanto para os ecossistemas. Como crítica a essa situação, surgem as propostas de alternativas ecologicamente mais benéficas para satisfazer as necessidades do turismo de massa: o conceito de Turismo Alternativo. Porém, apesar dos muitos projetos de ecoturismo ou turismo alternativo, dos existentes roteiros sobre como elaborar um projeto de ecoturismo que vise a sustentabilidade ambiental e dos muitos exemplos empíricos, poucos casos poderiam ser retirados da realidade serem usados como modelos de sustentabilidade. Em 1987, ocorreu a primeira iniciativa governamental de proceder a uma proposta de ordenação, com a criação da Comissão Técnica Nacional da qual faziam parte representante do Instituto Brasileiro do Meio Ambiente e dos Recursos Naturais Renováveis - IBAMA e do Instituto Brasileiro de Turismo - EMBRATUR e cujo objetivo era monitorar o Projeto de Turismo Ecológico.

Em 1992 realizou-se em Belize o Congresso Mundial de Ecoturismo, ocasião em que a atividade foi definida como "turismo dedicado à apreciação da natureza em forma ativa, com o objetivo de conhecer e interpretar os valores naturais e culturais existentes". (Dias, 1992. P:67)

Em junho de 1992 no Rio de Janeiro aconteceu a Conferência das Nações Unidas para o Meio Ambiente e o Desenvolvimento. Esse evento reuniu em torno de 180 países preocupados com a questão ambiental e tinha a finalidade de decidir quais as ações que deveriam ser implementadas para 
promover o Desenvolvimento Sustentável. Sua importância foi à incorporação da possibilidade de desenvolvimento a um meio ambiente saudável. Visava examinar a situação ambiental desde 1972, estabelecer mecanismos de transparência de tecnologias não poluentes aos países subdesenvolvidos e incorporar critérios e regras ambientais ao processo de desenvolvimento. Seu objetivo era criar estratégias de acordos internacionais e nacionais para beneficiar a preservação do meio ambiente e a expansão do desenvolvimento.

Há 31 anos a Organização das Nações Unidas convocou a primeira conferência mundial sobre meio ambiente e desenvolvimento. Em 2002, às vésperas de uma nova Cúpula sobre esse tema, na África do Sul, o desafio é estabelecer uma estratégia de ação que permita salvar o planeta. A primeira reunião convocada pela ONU foi a Conferência as Nações Unidas sobre Meio Ambiente Humano realizada em Estocolmo, na Suécia, em junho de 1972.

Nessa época, este tema ainda não fazia parte da agenda internacional nem era uma preocupação dos governos, que em sua maioria careciam de uma institucionalidade para o setor. $\mathrm{Na}$ declaração final de Estocolmo ressaltava-se a responsabilidade dos humanos na conservação de seu meio ambiente. Foi o início de um debate que ainda não acabou. Como conseqüência da conferência de 1972 foi criado o Programa das Nações Unidas para o Meio Ambiente.

No final de 1983, foi criada a Comissão Mundial sobre Meio Ambiente e Desenvolvimento (CMMAD) através da Assembléia Geral das Nações Unidas, em resposta à preocupação acerca do crescente impacto da atividade humana sobre os recursos naturais da Terra. A missão desse grupo de pessoas eminentes, presidido pelo Primeiro Ministro Gro Harlem Brundtlanda, da Noruega, nome que deu origem ao relatório sistematizado por esta comissão. A finalidade dessa comissão era reexaminar os problemas críticos do meio ambiente e desenvolvimento do planeta e formular propostas realistas para solucioná-los. Durante três anos, a CMMAD conduziu pesquisas e trabalhou junto ao público, executou estudos específicos feitos por técnicos, e consultou líderes em política, negócios, educação, ciência e desenvolvimento. 
Em 1987, a comissão lançou seu relatório conjunto, Our Commom Future ( Nosso Futuro comum), que registrou tanto sucessos como falhas no desenvolvimento mundial. A CMMAD encontrou alguns resultados positivos: a expectativa de vida está crescendo: a mortalidade infantil está decaindo; o grau de alfabetização é cada vez maior; as inovações técnicas e científicas são promissoras; e a produção de alimentos está crescendo mais rápida do que a população mundial.

O relatório caracteriza a situação da seguinte forma: "Quando o século começou, nem o número de seres humanos, nem a tecnologia existente tinham força para alterar os sistemas do planeta. À medida que o final do século se aproxima, não apenas o número de seres humanos, como suas atividades, têm essa força, mas, também, o que é mais importante, mudanças não esperadas estão ocorrendo na atmosfera, no solo, nas águas, entre as plantas e animais, e nas relações entre todos eles. O grau de mudança está superando a capacidade da ciência e da nossa capacidade em avaliar e deliberar.

Todavia, a maior contribuição feita pelo relatório não foi uma análise da atual situação mundial. Vale dizer preciosa e bem formulada, mas sim um grande passo para um diálogo e debate mundiais sobre os conceitos de desenvolvimento controlado. O relatório da CMMAD descreve desenvolvimento controlado como sendo "... não um estado fixo de harmonia, mas sim um processo de mudanças no qual a exploração de recursos, o gerenciamento dos investimentos, a orientação do desenvolvimento tecnológico e as mudanças institucionais são compatíveis com o futuro, bem como com as necessidades do presente".

Apoiando-se em uma diferente e inovadora era de crescimento econômico sustentável, a fim de combater a pobreza e melhorar as condições da vida humana em todo o mundo, a CMMAD tem possibilitado o engajamento em um vasto espectro de experiências, perspectivas, aptidões e interesse na procura de soluções criativas e bem sucedidas para nossos problemas em comum.

A RIO 92 enfatizou a importância de uma política que vise reduzir os impactos sociais e ambientais causados pelo sistema produtivo, debater sobre modelos de desenvolvimento onde predomine a justiça e a conservação do meio 
ambiente, promover a cooperação internacional que beneficie a preservação ambiental etc. (CRESPO, 1998) Seu documento de maior relevância, abrangência e alcance foi a "AGENDA 21" que proporcionou uma nova visão do mundo, um roteiro de ações que relata os compromissos dos países para se tentar alcançar o desenvolvimento sustentável com contenção, equilíbrio e prevenção atribuindo responsabilidade à todos. A viabilidade deste documento depende do empenho de cada Governo. A Agenda 21 foi assinada por aproximadamente 175 chefes de governo e representou um consenso internacional de implantação do Desenvolvimento Sustentável. É constituída de recomendações para que todos os países elaborarem sua "AGENDA 21" de acordo com suas realidades.

As principais recomendações da "AGENDA 21" são:

- Reconhecer a relação entre questões ambientais e desenvolvimento;

- Utilizar a energia de forma mais eficaz e desenvolver fontes de energia solar;

- Promover a educação ambiental dos agricultores e da população em geral;

- Plantar novas florestas e replantar as florestas danificadas;

- Eliminar a pobreza, ajudando os pobres a ganhar a vida, de forma a não contribuírem para os danos ambientais;

- Fixar multas para as pessoas e indústrias que poluem as águas e o meio ambiente;

- Preparar planos nacionais para o tratamento de lixo;

- Exigir que as indústrias adaptem métodos de produção mais seguros e mais limpos;

- Mudar padrões de consumo que destroem uma economia ambientalmente saudável, como o caso dos países ricos e das elites socioeconômicas locais.

A Agenda 21 Local é um processo participativo que visa através de estratégias alcançar 0 desenvolvimento sustentável priorizando seus problemas locais, para com isso subsidiar o sucesso das metas estabelecidas pela Agenda 21 Nacional.

Em fevereiro de 1997 criou-se a Comissão encarregada da 
elaboração e viabilização da Agenda 21 para o Brasil. Está Comissão definiu setores a serem analisados considerando a complexidade do país. São eles:

- Infra-estrutura e integração regional, para setores como transporte, energia;

- Cidades sustentáveis, que visa a sustentabilidade para o meio urbano;

- Agricultura sustentável, voltada para planejar os sistemas e modelos ideais para o campo;

- Gestão dos recursos naturais, preocupada com a proteção e uso sustentável dos recursos naturais;

- Redução das desigualdades sociais, que objetiva reduzir as disparidades sociais;

- Ciência, tecnologia e desenvolvimento sustentável. 


\section{TURISMO SUSTENTÁVEL}

A repercussão mundial acerca das questões ambientais também teve seu reflexo no turismo, envolvendo o Ecoturismo com bases no conceito de desenvolvimento sustentável. Este se caracteriza por uma estreita relação homem-natureza, e apoia-se a necessidade de integrar as áreas econômica e social, com a preservação e a melhor utilização dos recursos naturais, tornandose assim capaz de preservar o meio ambiente e proporcionar a satisfação das necessidades de sobrevivência das comunidades locais.

Desenvolvimento econômico e proteção ambiental estão relacionados diretamente. Porém, esta relação não é linear. Isto é um paradigma: Problemas ambientais nos países em desenvolvimento, como o Brasil, vêm do desenvolvimento econômico e da falta dele. Sem desenvolvimento econômico, dificilmente estes problemas se resolvem. Assim, mais desenvolvimento econômico não necessariamente significa mais problemas ambientais, e similarmente, menos desenvolvimento econômico não significa menos ou nenhum impacto ambiental. A chave do problema é a maneira como o desenvolvimento é feito. Esta maneira define se o desenvolvimento econômico pode ajudar ou não a melhorar a qualidade ambiental e qualidade de vida da população.

Segundo Carneiro, um empreendimento turístico de qualidade, deve envolver um bom gerenciamento, medidas de promoção socioeconômica e ações ambientalmente corretas, como forma de garantir perenidade ao investimento turístico.

Carneiro, abordando vários autores sobre as conceituações para sustentabilidade, retrata diferentes conceitos.

- Sustentabilidade considerada como uma obrigação geral e não específica (Solow. 1991).

- "Sustentabilidade implica a habilidade do sistema manter uma estrutura (organização) e função (vigor), com o passar do tempo, em face de estresse externo (resilência)" (Constanza, 1992, p.240). 
- "Ser sustentável é fornecer alimento, fibra e outros recursos naturais e sociais necessários para a sobrevivência de um grupo - sociedade nacional ou internacional, setor econômico ou categoria residencial, de modo que tais recursos essenciais sejam mantidos para as gerações presentes e futuras" (Wimberly, 1993, p. 1).

- Sistema será sustentável se existe um cenário de manejo trazendo-o para o estado desejado ou dinâmico. Quando não existe a possibilidade de manejo, ou quando ele não pode ser aplicado devido as limitações externas (limitação financeira), o sistema é dito insustentável (Voinov, 1990).

O conceito de sustentabilidade é conflitante, se tornando muitas vezes em uma questão mais política do que ambiental. O Estado atua como intermediador e, depender do nível de forças sociais que apoiam o uso sustentável dos recursos naturais, pode interferir favoravelmente na sua resolução, exercendo o seu poder em função do bem- estar social e ambiental.

O conceito de Desenvolvimento Sustentável dado pelo Relatório da Comissão Mundial sobre Meio Ambiente e Desenvolvimento gira em torno da satisfação das necessidades humanas básicas e expectativas de uma vida melhor. Relata também que o atual modelo de desenvolvimento não visa essa satisfação. O Relatório lembra que "a pobreza reduz a capacidade das pessoas para usar os recursos de modo sustentável, levando-as a exercer maior pressão sobre o meio ambiente".(CMMAD, 1998, p. 53 apud Figueiredo, 1999:83)

Promover e desenvolver turismo com bases culturais e ecologicamente sustentáveis, promover e incentivar investimentos em conservação dos recursos culturais e naturais utilizados, fazer com que a conservação beneficie naturalmente comunidades envolvidas, ser operado de acordo com os critérios de mínimo impacto para ser uma ferramenta de proteção e conservação ambiental e cultural, educar e motivar pessoas através da participação e atividades a perceber a importância de áreas naturais e culturalmente conservadas, são tarefas que devem ser desenvolvidas pelo ecoturismo. 


\subsection{Evolução do Turismo}

A origem do turismo ${ }^{1}$ é discutida por diferentes autores. Uns defendem que no séc. VIII a.C. as viagens para assistir os jogos Olímpicos na Grécia representavam viagens turísticas. Outros acreditavam que pelos Fenícios terem inventado a moeda e o comércio também o fizeram com o turismo. Os Romanos também foram referencial para o surgimento do turismo em virtude das estradas construídas naquela época e as viagens para o lazer. (Figueiredo, 1999:89)

Para Trigo (1995), após a Segunda Guerra Mundial, houve uma elevação do nível de renda, a instituição das férias para os trabalhadores e a consciência do direito ao lazer, entendido como toda atividade desenvolvida fora do sistema produtivo, das obrigações sociais, religiosas e familiares, que viabilizaram o surgimento e crescimento do turismo.

A partir de 1950, o turismo transformou-se em uma atividade de grande porte em termos econômicos, sociais e culturais, tendo início o turismo de massa. Em 1960 explode com as possibilidades do lazer e, portanto como fonte de lucros e investimentos. Essa evolução dos acontecimentos econômicos e sociais do mundo moderno transformou o turismo em um setor bastante promissor, sendo uma atividade que atende a demanda do lazer e mobiliza um enorme volume de recursos. É uma atividade econômica, geradora de riqueza, estando o seu desempenho relacionado ao comportamento da renda, sua distribuição e ao tempo livre disponível.

Essas características do turismo o fazem integrar na política de valorização do bem-estar, através da conservação dos recursos naturais e a melhoria dos recursos humanos. O turismo no mercado profissional traz melhorias na qualidade, produtividade e na remuneração dos trabalhadores, mas são necessários estudos e ações para que verdadeiramente produza benefícios sociais.

\footnotetext{
1 "A palavra turismo provém do latim "tornare" que quer dizer "dar uma volta, voltar ao ponto inicial." (Figueiredo, 1999:89)
} 
A relação turismo e meio ambiente merece destaque, já que o turismo pode gerar efeitos desastrosos ao meio ambiente, caso não seja adequadamente dimensionado. A década de 70 marcou o início da preocupação com o meio ambiente dando ênfase à ameaça aos recursos naturais e à perda de lucro que a degradação provoca, passando o turismo passa a ser um instrumento de preservação.

O Instituto Brasileiro de Turismo - EMBRATUR foi criado em 1966 e tem como competências, entre outros: propor ao Governo Federal normas e medidas necessárias à execução da Política Nacional de Turismo e executar as decisões que, para esse fim, Ihe sejam recomendadas; inventariar, hierarquizar e ordenar o uso e ocupação de áreas e locais de interesse turístico e estimular o aproveitamento dos recursos naturais e culturais que integram o patrimônio turístico, com vistas à sua preservação; estimular as iniciativas destinadas a preservar o ambiente natural e a fisionomia social e cultural dos locais turísticos e das populações afetadas pelo seu desenvolvimento.

Barreto, discutindo vários autores, contribuiu para o debate acerca do turismo quando o turismo ao longo do tempo foi conceituado segundo diferentes óticas. Em 1991 o economista austríaco Hermann Von Schullern Zu Schattenhazen definiu o turismo como "conceito que compreende todos os processos, especialmente os econômicos, que se manifestam na chegada, na permanência e na saída do turista de um determinado Município, País ou Estado".(Barreto, 1995:9)

A Associação Internacional de Especialistas na Ciência do Turismo - AIEST adotou a seguinte definição: "O turismo é o conjunto das relações e dos fenômenos produzidos pelo deslocamento e permanência de pessoas fora do seu local de domicílio, sempre que ditos deslocamentos e permanências não estejam motivados por uma atividade lucrativa, esta visão é dos autores suíços Walter Hunziker e Kurt Krapf”.(Barreto, 1995: 11)

A Organização Mundial do Turismo - OMT "definiu como sendo a soma das relações e de serviços resultantes de um câmbio de residência temporário e voluntário motivado por razões alheias a negócios ou profissionais".(De La Torre, $1992: 19$ apud Barreto, 1995:12) O Consultor de 
Turismo da Organização Internacional do Trabalho (1971) e Presidente Eleito da União Árabe Internacional de Turismo (1972), Salah-Eldin Abdel Wahab, definiu o turismo como:

"Uma atividade humana intencional que serve como meio de comunicação e como elo de interação entre povos, tanto dentro como fora de um país. Envolve deslocamento temporário de pessoas para outras regiões ou países visando a satisfação de outras necessidades que não a de atividades remuneradas." (Trigo, 1995:10)

Entre as modalidades de turismo destaca-se o turismo ecológico que não é um segmento de turismo de massa, o mais convencional, e dividi-se em:

- Turismo Ambiental que visa o estudo do meio, e pode ser praticado nos mais diversos tipos de destinos, sejam eles urbanos ou rurais;

- Turismo Rural é uma modalidade turística de recente crescimento, relacionada com a necessidade que os habitantes das grandes cidades têm tido de se afastar não só do meio, mas também do estilo de vida urbano;

- Turismo de Aventura esta em moda nos grandes centros do Brasil é essencialmente rural e combina o turismo com a prática de esportes ligados a natureza;

- Ecoturismo não é uma modalidade de turismo, mas uma filosofia de turismo relacionada com a conservação do meio ambiente, é um segmento da atividade turística que utiliza de forma sustentável o patrimônio natural e cultural, incentiva sua conservação e busca a formação de uma consciência ambientalista através da interpretação do ambiente, promovendo o bem-estar das populações envolvidas. (Simões, 2000 p: 245)

Para SWARBROOKE (2000), em termos simples, ecoturismo significa simplesmente que a principal motivação para a viagem é o desejo de ver ecossistemas em seu estado natural, sua vida selvagem assim como sua população nativa. Contudo, muitas vezes se considera o ecoturismo como sendo 
mais do que isso. Seus defensores afirmam que ele se relaciona também com o desejo de ver os ecossistemas preservados e que a população local viva melhor por conta dos efeitos do turismo.

Para uma melhor compreensão do conceito de ecoturismo é necessário destacar algumas características: o ecoturismo tem suas raízes na natureza e no turismo, através dele o valor da vida natural, dos interesses das populações locais e a importância de observar os danos causados ao meio ambiente tem crescido. Ele envolve compromisso sério com a natureza, preocupação com interesses de ordem ambiental, econômica e social.

Para Ângelo-Furlan (1996) o turismo deve satisfazer a sociedade e ao mesmo tempo a necessidade de preservação da natureza diz que:

Todo turismo deveria ser ecológico no sentido de que para usufruir da natureza é preciso ter conhecimento prévio do ambiente a ser colocado à disposição do uso turístico. Todo turismo deveria se pautar no funcionamento da natureza e nos seus limites ecológicos ao projetar infraestruturas e equipamentos turísticos. Qualquer tipo de turismo tem de se adequar às fragilidades do meio a ser capaz de gerir e controlar impactos ambientais. Para a natureza não interessa quem usufrui de e sim como se usufrui. (Ângelo-Furlan, 1996 apud Figueiredo, 1997:57)

Sobre isso Western (1995) acrescenta que "Conservação e turismo que neguem os direitos e interesses das comunidades locais estão fadados ao fracasso, quando não considerados totalmente ilegais".(Western, 1995 apud Figueiredo, 1997:57)

Considerando que o Ecoturismo é uma tendência em termos de turismo mundial que aponta para o uso sustentável dos atrativos do meio ambiente e das manifestações culturais, devemos ter em mente que somente teremos condições de sustentabilidade caso haja harmonia e equilíbrio entre o resultado econômico, mínimos impactos ambientais e culturais, e satisfação do ecoturista e da comunidade.

O Ecoturismo é visto como um conjunto de princípios aplicáveis à qualquer tipo de turismo que se relacione com a natureza. Seu potencial tem 
despertado interesses dos Governos, principalmente dos países em desenvolvimento que são ricos em áreas naturais. Temos, portanto, que lembrar que o ecoturismo requer um planejamento cuidadoso, regulamentos rígidos, onde todos têm que estar cientes de que o bom desempenho dos seus papéis é fundamental para o sucesso. Karen Ziffer (1989) diz que o nível da demanda para o Ecoturismo é influenciado por três fatores básicos:

- Crescimento do turismo em geral;

- Crescimento das viagens especializadas;

- Aumento dos conhecimentos, interesses e preocupações com o meio ambiente. (Ziffer, 1989:10-11 apud Figueiredo, 1999:76).

O turismo está interligado ao meio ambiente, sendo o patrimônio natural uma peça essencial. A política de preservação do meio ambiente visa um controle do crescimento, sem a destruição da originalidade dos atrativos. $O$ turismo sustentável contempla exatamente essa visão de equilíbrio entre o desenvolvimento econômico e a preservação do meio ambiente. Hoje o maior agressor é o turismo de massa, o qual é desordenado e não tem como base um turismo de qualidade.

Dóris Ruschmann (1994) declara que durante o seu desenvolvimento, o turismo apresentou fases de relacionamento com o meio ambiente. A primeira fase foi de descoberta do meio ambiente. No segundo momento, a proteção era algo desnecessário, alterando o ambiente e causando a sua degradação rápida, principalmente através do turismo de massa, quando ocorreu um domínio brutal do turismo sobre a natureza. A quarta fase foi a de reparação e renovação do turismo através da revalorização do meio ambiente, tendo como norte o conceito de Desenvolvimento Sustentável e posteriormente o ecoturismo. (Ruschmann, 1994 apud Figueiredo, 1999)

Hoje o turismo é considerado uma das maiores indústrias, seu desempenho é superior à indústria de automóvel, de aço, de eletrônica e à agricultura. Dados do Conselho Mundial de Viagens e Turismo indicam que o setor emprega 127 milhões de trabalhadores (1 em cada 15 no mundo todo). $A$ Organização Mundial de Turismo indica que o turismo internacional cresceu mais 
de $57 \%$ na década passada (Lindberg \& Hankins, 1995).

Várias medidas podem ser adotadas para diminuir os impactos ambientais do turismo como o controle, redução ou eliminação dos produtos nocivos ao meio ambiente natural, o respeito aos interesses da população local, como suas tradições e cultura, o zelo pela preservação de áreas protegidas ou ameaçadas. O turismo deve respeitar a compatibilidade do uso com a proteção do meio ambiente.

Atualmente, o planejamento da evolução do turismo através do enfoque do Desenvolvimento Sustentável apresenta-se como a forma preventiva ideal para proteção dos meios visitados, conservando a natureza, oferecendo conforto e satisfação ao turista sem agredir a originalidade das comunidades receptivas.

\subsection{Evolução do Ecoturismo}

Ao fim do século XIX, os primeiros parques nacionais pretendiam preservar a natureza do contato humano. Já em meados da década de vinte, a proteção era o conceito chave, e durante as últimas três décadas do século XX a gestão das áreas protegidas passou a comandar um discurso que identificava a impossibilidade de manter áreas isoladas das atividades humanas. Assim, o grande desafio do século XXI será a questão da gestão integrada, que supõe a participação das comunidades vizinhas, ou inseridas nas áreas de conservação, na gestão sustentável dos espaços naturais.

O Ecoturismo é uma atividade que busca a valorização não só da natureza, mas também dos bens culturais, históricos arquitetônicos. É através da valorização da cultura e do respeito à tradições, hábitos e tecnologias tradicionais, que os moradores dos lugares visitados dão indiretamente beneficiados. Assim conclui-se que, no decorrer do tempo, a idéia evoluiu a partir de um enfoque inicial relativo somente à conservação de áreas protegidas, para referências posteriores aos componentes naturais e culturais do ambiente, culminando com a 
atual preocupação onde são ressaltadas as implicações sociais e o estabelecimento de uma ligação estreita entre o turismo como atividade comercial, lucrativa e a participação das comunidades.

A atividade turística ocupa papel importante no mundo moderno, por movimentar grande quantidade de dinheiro e contribuir para o crescimento da economia. Dos segmentos do turismo, o Ecoturismo é o que mais cresce, cerca de $20 \%$ ao ano, com perspectiva de aumento, é um fenômeno característico do final do séc. $X X$, em conseqüência da crescente preocupação com o meio ambiente. É o segmento que mais se aproxima da proposta de Desenvolvimento Sustentável.

Ao contrário do turismo predatório, Turismo de Massa, surge o ecoturismo como uma estratégia conservacionista do meio ambiente via o turismo, sendo um instrumento utilizado para frear o turismo vigente. Ziffer (1989) diz que o ecoturismo é a "forma de turismo inspirada primordialmente na história natural de uma área, incluindo suas culturas indígenas”.(Ziffer, 1989:6 apud Figueiredo, 1999:120) Segundo a EMBRATUR (1994:19)

Ecoturismo é um segmento da atividade turística que utiliza de forma sustentável o patrimônio natural e cultural, incentiva a sua conservação e busca a formação de uma consciência ambientalista, promovendo o bem-estar das populações envolvidas. (Diretrizes para uma política nacional de Ecoturismo, MICT/MMA, 1994)

- A Sociedade Americana de Ecoturismo definiu o ecoturismo como a viagem responsável a áreas naturais, visando preservar o meio ambiente e promover o bem-estar da população local. O Ecoturismo está deixando de definir-se como turismo de natureza em pequena escala para estabelecer-se como um conjunto de princípios aplicáveis a qualquer turismo que se relacione com a natureza. (Sociedade Americana de Ecoturismo apud Figueiredo, 1999:99)

- Ecoturismo é provocar e satisfazer o desejo que temos de estar em contato com a natureza, é explorar o potencial turístico visando à conservação e ao desenvolvimento, é evitar o impacto negativo sobre a ecologia, a cultura e a estética. (Lindberg \& Hankins, 1995:18). 
- Molina definiu ecoturismo como o turismo que tem lugar em ecossistemas e ambientes naturais e que, mesmo assim está orientado a favorecer o conhecimento e a aprendizagem das manifestações naturais mediante certas interações de baixo impacto. (Molina, 1991:88-89 apud Figueiredo, 1999:99).

O Ecoturismo tem despertado à sensibilidade a natureza, mas ainda está em desenvolvimento, com perspectivas de expansão. Seu objetivo é aliar o turismo à preservação da natureza, ou seja, encontrar o equilíbrio entre os dois que além de ser o objetivo passa a ser também um desafio.

Para o sucesso do Ecoturismo são necessárias algumas etapas:

- Pesquisa da oferta e demanda;

- Zoneamento Turístico-ecológico

- Seleção de áreas prioritárias;

- Elaboração de projetos de infra-estrutura;

- Execução e controle do projeto. O Ecoturismo tem que atentar para a capacidade de carga dos lugares visitados, a integração cultural dos povos, a conservação da base dos recursos naturais utilizados, gerando mecanismos de distribuição de renda. Com este planejamento o Ecoturismo traz benefícios como:

- Criação de áreas de preservação;

- Criação de emprego, lazer e fixação da população no meio rural;

- Proporciona a educação ambiental, enfatizando a importância da preservação do meio ambiente.

O rápido crescimento do ecoturismo aumentou a pressão sobre os recursos naturais de interesses turísticos, dificultando o planejamento adequado, gerando conseqüências negativas como a degradação ambiental decorrente de infra-estrutura inadequada e acúmulo de lixo gerando poluição, a instabilidade e dependência econômica, quando a geração de emprego e renda é toda decorrente da prática do turismo. 
A Educação Ambiental para atividade turística é um ponto importante, é a forma de conhecer, divulgar e preservar o patrimônio histórico, cultural e natural. Mendonça (1996) ressalta o perigo da falta de conhecimento:

A atividade turística tem se desenvolvido de tal forma que os indivíduos escolhem o lugar que vão visitar por critérios que não incluem forçosamente a personalidade do lugar, seus aspectos peculiares e especiais, suas características ambientais mais fortes - tais como vegetação, o relevo, a hidrografia, o povo do lugar e sua cultura, sua música, seus hábitos, sua culinária. E sem esse conhecimento fica difícil respeitar. Impera uma grande superficialidade na relação com a natureza e com as populações locais. (Mendonça, 1996 apud Figueiredo, 1997:62)

É impressionante o desconhecimento generalizado que a população tem em relação ao potencial turístico natural de seu próprio país. Essa ignorância é prejudicial porque impede a proteção e regulamentação das áreas. Para a Prof. Doris Ruschmann (1990):

"Independentemente dos diversos enfoques do planejamento turístico, ressalta-se a necessidade de o processo ocorrer de forma integrada, e de que deve ter por objetivo o desenvolvimento coerente dos fenômenos físicos, econômicos, sociais, culturais, técnicos e ambientais, visando à satisfação dos turistas e dos empreendedores, além da preservação do meio ambiente. $\mathrm{Na}$ maioria dos casos a grande motivação das viagens turísticas se refere aos aspectos ambientais. Entretanto, o fluxo descontrolado de turistas poderá descaracterizar completa, e muitas vezes definitivamente, as atrações que motivaram sua visita. Por isso, o planejamento se apresenta como o fundamento para o desenvolvimento turístico equilibrado evitando assim que o turismo destrua as bases que o fazem existir. (Ruschmann, 1990:65-69 apud Trigo, 1999:45-46)

O desenvolvimento do ecoturismo a médio e longo prazo depende fundamentalmente da preservação do patrimônio ambiental das regiões, promoção e divulgação a níveis internacionais, criação de ofertas atraentes e qualificação dos profissionais da área. 


\subsection{Turismo Ecológico versus Ecoturismo}

Quando se fala em ecoturismo, o termo turismo ecológico caminha junto. Para a professora da Universidade Estadual do Ceará, Luzia Neide Coriolano, todo turismo deve ser ecológico, ou seja, usar racionalmente o ambiente. "Qualquer tipo de turismo seja de massa ou de minoria precisa atender as exigências da ecologia, integrando lazer, conservação da natureza/sociedade e valorização da cultura", afirma.

Já o ecoturismo, na opinião da professora, é uma modalidade de turismo dirigida a pequenos grupos e motivada pela descoberta de que a natureza é um recurso natural que pode ser transformada em recurso turístico. "Sendo assim, ele é também uma forma a mais de consumo e dessa vez mais perigosa porque invadiu as entranhas da natureza, que deveriam ser respeitadas", defende.

Embora a essência do turismo seja o entretenimento ou o lazer e a essência da ecologia seja a conservação ambiental, Luzia Neide acredita que possa haver uma viagem responsável que procura evitar os impactos negativos sobre a ecologia, a cultura e a estética. Para ela, deve haver além da conservação, a proteção total, o que eqüivale a apenas contemplar e observar a natureza." É o lazer em áreas preservadas, com limitações de usos, por serem ecossistemas de grandes fragilidades, mas que proporcionam ao homem momentos de contemplação da natureza e oportunidade de encontro consigo mesmo. É um turismo especial, dirigido a grupos especiais, evitando grandes concentrações e, sobretudo integrando o turismo enquanto atividade econômicosocial ao meio ambiente natural".

À semelhança do que ocorre com o conceito de sustentabilidade e de desenvolvimento sustentável, existe uma indefinição em torno do que seja turismo ecológico e ecoturismo.

Selva e Coutinho (2000) referindo-se ao impasse sobre a utilização dos termos observam que a incompatibilidade entre ecoturismo e turismo ecológico é a mesma entre teoria e prática. A expressão ecoturismo, por 
sua vez, surgiria para designar a modalidade de turismo cujas bases estão fincadas nas propostas do desenvolvimento sustentável. (Faria e Carneiro, 2000, p:70)

A relação do turismo com o meio ambiente dá-se principalmente por meio da paisagem, transformada em produto a ser consumido.

\subsection{Ecoturismo no Brasil}

O Brasil tem uma superfície de $8.511 .596,3$ km2. No âmbito dessa extensão continental abrange desde regiões equatoriais ao norte até áreas extratropicais ao sul, diferenciadas climática e geomorfologicamente, com uma extraordinária diversidade ecológica.

O Ecoturismo no Brasil ainda se desenvolve de forma desordenada, mesmo com a certeza de que o mesmo tenha potencial para tal prática, possui regiões ricas em biodiversidade. No entanto, a imagem reinante no cenário internacional é a da desigualdade social e da violência. Os danos ambientais provocados pelo desenvolvimento descontrolado do turismo podem causar poluição, degradação da paisagem e destruição da fauna e flora, entre outros. A poluição dos recursos hídricos resulta na redução drástica de atividades de recreação e lazer e deflagrar o afastamento de turistas.

“... O Ecoturismo praticado no Brasil é uma atividade ainda desordenada, impulsionada, quase que exclusivamente pela oportunidade mercadológica, deixando a rigor de gerar os benefícios socioeconômicos e ambientais esperados e comprometendo, não raro, o conceito e a imagem do produto ecoturístico brasileiro nos mercados interno e externo." (Embratur, 1994:9 apud Trigo, 1999:49)

Se o ecoturismo no Brasil encontra-se em um estágio de 
desenvolvimento recente, o momento de introduzir uma política de âmbito nacional para o setor é agora e urgente. Tal política deve orientar governos e legislativos para a implantação de suas estratégias de regulamentação e controle, assim como orientar agências de fomento para criar e facilitar o acesso a incentivos fiscais e financiamentos. Não se pode esquecer do estímulo ao acesso à capacitação e a tecnologias apropriadas ao empresariado e da promoção da conscientização e educação dos visitantes, entre outras prioridades.

No Brasil, o ecoturismo é discutido desde 1985. No âmbito governamental, a primeira iniciativa de ordenar a atividade ocorreu em $1987 \mathrm{com}$ a criação da Comissão Técnica Nacional, constituída por técnicos do Instituto Brasileiro do Meio Ambiente e dos Recursos Naturais Renováveis - IBAMA e do Instituto Brasileiro de Turismo - EMBRATUR, para monitorar o Projeto de Turismo Ecológico, em resposta às práticas existentes à época, pouco organizadas e sustentáveis.

O termo "ecotourism" ou ecoturismo é atribuído ao mexicano Hector Ceballos Lascurain, que deu uma primeira definição do conceito em 1983, "viajar para uma região relativamente selvagem com o objetivo específico de estudar, admirar e desfrutar da paisagem, plantas e animais, assim como das manifestações culturais existentes".

O uso do termo ganhou força. Porém, este tipo de turismo (viagens responsáveis para áreas naturais que conservam o meio-ambiente e sustentam o bem-estar das comunidades locais), na realidade existia antes disto, mas era parte do segmento de viagens para destinos de natureza ou para destinos "exóticos". No Brasil, já tinha ecoturismo nos anos 80 : os cruzeiros no Rio Solimões e Rio Negro da Safari Ecológico, o Macuco Safaris em Foz de Iguaçu, a Pousada Caimã no Pantanal, o Rancho Grande em Rondônia, o Amazon Lodge em Amazonas, Christoph Hridina de Brasília e operadoras nacionais com Ambiental e Freeway são desta época. A Silvana Campello introduziu o conceito turismo ecológico na Embratur em 1989 e junto com Predrag Pancevski criou o primeiro curso de guia de ecoturismo. 


\subsection{Diretrizes no Brasil}

Em 1994, uma iniciativa conjunta entre o Ministério d Industria, Comércio e Turismo e o Ministério do Meio ambiente, dos Recursos Hídricos e da Amazônia Legal propôs as diretrizes para uma Política Nacional de Ecoturismo. Tais diretrizes têm, desde então, norteado oficialmente o desenvolvimento do ecoturismo no Brasil.

Segundo essas diretrizes, o conceito nacional de ecoturismo pode ser expresso com "um segmento da atividade turística que utiliza de forma sustentável o patrimônio natural e cultural, incentiva sua conservação e busca a formação de uma consciência ambiental através da interpretação do ambiente, promovendo o bem-estar das populações envolvidas".

O documento traz as principais recomendações e diretrizes para governos, empresas privadas, entidades não governamentais, acadêmicas de pesquisa, agências de fomento e investimentos, municípios e comunidades envolvidas com o ecoturismo, atividade que vem apresentado forte crescimento desde a Conferencia RIO 92.

Assim, o ecoturismo representa uma alternativa de desenvolvimento econômico sustentável que utiliza racionalmente os recursos naturais de uma região, sem comprometer sua capacidade de renovação e conservação. Nesse segmento, diversos nichos de mercado são identificados como formas de praticar o ecoturismo: contemplação da flora, da fauna e da cultura local; safáris fotográficos; trilhas; mergulho de observação; atividades esportivas em rios, montanhas e cachoeiras.

A possibilidade do ecoturismo como alternativa de desenvolvimento sustentável, tem conduzido a um rápido crescimento do mercado de produtos turísticos denominados "verdes". Surgem regras de regulamentação que cresceram ao lado dessas atividades, usadas para indicar um modelo seguro de práticas definidas como sustentáveis, utilizadas, tanto internamente por entidades privadas, quanto por organismos públicos ligados ao turismo e por membros da sociedade civil. 
O ecoturismo bem sucedido não pode prescindir de um planejamento sistematizado, com visão de longo prazo e estrita obediência à legislação; e exige uma gestão adequada, o que significa poder contar com administradores competentes, providos de conhecimentos técnicos.

Pode-se dizer que o sucesso da atividade será sempre a resultante de inúmeros fatores, mas hoje, é destacada a necessidade de cada organização, instituição, seja pública ou privada, voltar-se ao futuro, pronta a assimilar novas informações.

O planejamento é um processo contínuo de busca de alternativas que possam ajudar no acerto de tomada de determinadas decisões. Permite a escolha, dentre as diferentes alternativas, daquela que oferece as melhores chances de sucesso, levando em consideração os recursos, a equipe, o tempo e a estrutura disponíveis.

O planejamento permite criar o cenário que se deseja, evitar situações indesejáveis e adaptar-se ao inesperado, isto é, para transformar atrativos em produtos ecoturísticos é preciso planejamento. Assim é possível identificar:

- que a localidade tem a oferecer;

- Quais são os seus pontos fortes e fracos;

- Quais são as responsabilidades e os papéis dos diversos agentes ligados ao ecoturismo;

- Quais são os grupos de pessoas que consomem ou estão dispostas a consumir produtos ecoturísticos;

- Produtos que possam competir no mercado ecoturístico, oferecendo atrativos que estimulem o mercado consumidor adequado.

Sendo assim, vários setores da sociedade participarão, como: poder público, população local, fornecedores, operadores de turismo, agentes de viagens entre outros. 


\subsection{A Criação de Produtos e Destinos}

O Brasil tem 8.547.403 $\mathrm{Km}^{2}$ abrangendo $47,9 \%$ da América do Sul, $5^{\circ}$ País do Globo em extensão, tem 26 Estados além do Distrito Federal. Seu litoral tem $7.400 \mathrm{Km}$ de extensão, possui 34 parques nacionais, 70 cidades históricas, seu clima predominantemente tropical abriga florestas equatoriais e tropicais, manguezais, pantanal. É a maior economia da América Latina, possui 154 milhões (IBGE) de habitantes. ${ }^{2}$

O turismo no Brasil como fenômeno social começou depois de 1920 com a criação da Sociedade Brasileira de Turismo em 1923, em 1927 as primeiras Diretrizes da Política Nacional de Turismo é estabelecida, e a partir de 1996 o setor passa a ser reconhecido como importante atividade econômicosocial capaz de desenvolver a economia.

Valorizar o original não significa falta de conforto e qualidade. A maioria dos lugares procurados pelos ecoturistas fica longe dos grandes centro urbanos e próximo às regiões naturais conservadas, como florestas, montanhas, praias desertas. Nos lugares distantes as dificuldades de acesso, a falta de energia elétrica, e a forte sazonalidade são obstáculos ao conforto e à segurança, itens tradicionalmente exigidos pelos turistas. Deve-se lembrar, no entanto, a diferença entre coisas rústicas e precárias: o rústico pode significar simplicidade, falta de recursos materiais e tecnológicos; precário significa um produto ou serviços mal cuidados, sujos, desorganizado.

Ao planejar as atividades ecoturísticas em um pólo é de vital importância conhecer previamente, o tipo de turista que freqüentará aquele destino. $\mathrm{O}$ fato de uma localidade possuir atrativos turísticos naturais ou culturais, não é o suficiente para ser considerada um destino ecoturístico de qualidade. Acompanhamento a oferta ecoturística é imperativo oferecer uma gama de serviços complementares que dêem condições desses recursos serem apropriados ao consumidor. É preciso que o destino ofereça hospedagem, alimentação, atrações e programas que possam ser adquiridos pelo visitante. A

\footnotetext{
${ }^{2}$ TRIGO, 1995.
} 
tarefa de transformar recursos em produtos, é muito importante e pode significar o sucesso ou o fracasso da empreitada.

O ecoturismo é diferente do turismo convencional, porque considera que o ambiente não deve ser transformado a fim de atender às expectativas dos visitantes; esses devem ser preparados para a experiência da visitação. Por conta desse perfil diferenciado, o ecoturista tem interesses e necessidades que exigem, de quem planeja produtos e atividades, a observação de alguns critérios:

- Utilizar os recursos naturais e culturais de forma sustentável;

- Oferecer produtos de elevada qualidade aos visitantes;

- Contribuir para a distribuição justa dos benefícios econômicos gerados;

- Possibilitar o desenvolvimento de empreendimentos criados e gerenciados pelas próprias comunidades.

\subsection{Tendências do Ecoturismo}

Com a constatação de que o turismo é uma atividade capaz de desenvolver a economia, o Brasil passou a preocupar-se mais com seus recursos naturais e perceber que através deles poderia desenvolver-se via o turismo. A partir de 1981 o Brasil criou a Política Nacional do Meio Ambiente e com a Lei 6.938 instituiu o Conselho Nacional do Meio Ambiente. Elaborou uma das mais avançadas e modernas legislações do Mundo em relação à proteção ambiental, uma legislação tanto para regular o uso das terras como das águas e conservar nossas reservas ecológicas, parques e outros locais que proporcionam o turismo ecológico.

Temos que ter claro que a exploração turística dos recursos naturais deve ser feita com qualidade, cuidado com o turista, com o ambiente, incluindo é claro a comunidade local envolvida, dentro desta perspectiva a obtenção de lucro terá retorno com qualidade. 
Nos últimos anos o turismo tem registrado taxas expressivas de crescimento na economia Brasileira, em termos de geração do produto total coloca o Brasil entre as oito principais economias do Mundo Ocidental com PIB de US $\$ 320$ bilhões, impactando 52 segmentos diferentes da economia do país.

É necessário conhecimento da realidade e das futuras tendências para termos um turismo de qualidade, com bons recursos humanos obtidos através do atendimento das necessidades básicas do ser humano como educação, saúde. Para Beni (1991) três são os elementos importantes para o futuro do turismo: Inovação (criatividade, imaginação, questionamentos); desempenho (produtividade) e qualidade (profissionalismo, busca permanente da satisfação do cliente). Como o turismo abrange uma gama muito grande de serviços, conseguir integrar todos os setores numa proposta de qualidade é uma tarefa difícil, demorada, mais imprescindível. (Beni, 1991:7 apud Barreto, 1995:109)

\subsection{Impactos do Ecoturismo}

O crescente envolvimento da sociedade nas questões ambientais, pressionando governos e instituições para o estabelecimento de requisitos cada vez mais rígidos quanto ao impacto ambiental na implantação de empreendimentos, aliado a uma crescente busca do homem por uma relação íntima e freqüente com a natureza, recomenda a não restrição do conceito de ecoturismo. Este passa, atualmente, por uma transição de "produto turístico" para um "conceito de viagem", sendo que os componentes da definição podem vir a ser integralmente absorvidos por outros segmentos ou atividades do turismo, que talvez hoje não sejam considerados ecoturísticos, mas cuja evolução deve ser incentivada. 


\section{Aspectos Ambientais}

\section{Pontos Positivos}

- Destina recursos financeiros para a conservação e incentiva a recuperação das áreas degradadas;

- Estimula levantamentos de fauna e flora e incentiva a pesquisa científica;

- Um turismo em pequena escala;

- Mais ativo do que outras formas de turismo;

- Promove a educação ambiental e maior consciência ambiental nas populações;

- Viabiliza tecnologias ambientalmente sustentáveis;

- Empreendido por turistas esclarecidos e bem educados, conscientes das questões relacionadas a sustentabilidade, além de ávidos por aprender mais sobre estes temas;

- Estimula a implantação de infra-estrutura básica, saúde, comunicação, segurança, educação e comércio;

- Valoriza áreas naturais e cria condições de unir desenvolvimento e conservação;

- Menos espoliativo das culturas e da natureza locais do que as formas "tradicionais" de turismo (SWARBROOKE 2000).

\section{Pontos Negativos}

- Alterações nos comportamentos, hábitos alimentares e na reprodução dos animais silvestres pelo excesso de visitação e/ou presença de lixo;

- Mudanças numéricas nas populações silvestres;

- Comércio ilegal de espécies silvestres e de artesanatos que utilizam órgãos, penas ou couro de animais;

- Poluição do ar, água, solo, sonora e visual; 
- Abertura de estradas, trilhas e atalhos inadequados;

- Compactação e erosão do solo;

- Todos conhecemos os problemas causados pelo turismo de massa. E um destino de ecoturismo pode se tornar turismo de massa, quando excessivamente divulgado e concebido de forma irresponsável;

- O ecoturismo deve dizer respeito a ecossistemas, e ecossistemas dizem respeito à vida selvagem e às pessoas. Para os ecoturistas, portanto, as pessoas e a vida selvagem devem ter a mesma importância.

\section{Aspectos Econômicos}

\section{Pontos Positivos}

- Gera renda e emprega muita gente;

- Pode utilizar a infra-estrutura já existente;

- Desenvolve-se com produtos locais;

- Complementa outras atividades econômicas;

\section{Pontos Negativos}

- Inflação;

- Na baixa temporada muita gente pode ficar sem emprego, as atividades dependem das estações do ano;

- Pode haver prejuízos econômicos como conseqüência de boatos, problemas com doenças, mudanças no setor financeiro;

- A economia pode ficar dependente do ecoturismo como única fonte de renda.

\section{Aspectos Socioculturais}

\section{Pontos Positivos}

- Contribui para a educação;

- Estimula o entendimento e a paz; 
- Reduz barreiras entre as pessoas, em razão da raça, cor, sexo, origem cultural, política ou religiosa;

- Reforça a conservação de heranças e tradições, valoriza a cultura local.

Pontos Negativos

- Gera antipatia pelo excesso de visitantes;

- Descaracterização da cultura local;

- Desentendimento entre a comunidade local e novos moradores;

- Estimula aumento da criminalidade.

\subsection{Pólos Ecoturísticos no Brasil}

O desenvolvimento sustentável do ecoturismo deve considerar a gestão de todos os ambientes, os recursos e as comunidades receptoras, de modo a atender às necessidades econômicas, sociais, vivenciais e estéticas, enquanto a integridade cultural, os processos ecológicos essenciais e a diversidade biológica dos meios humano e ambiental devem ser mantidos através dos tempos.

Figura 1: Mapa dos Pólos de Ecoturismo

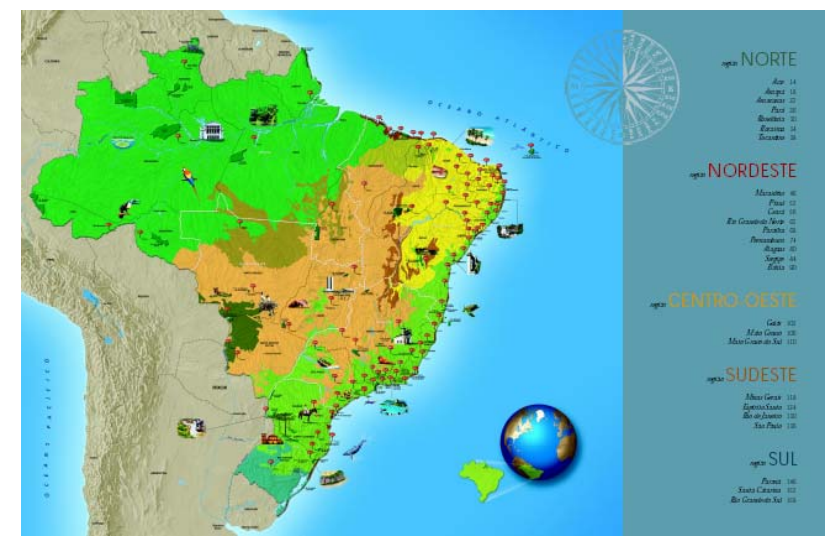

Fonte: Embratur 
WIGHT (1993) identificou nove princípios que devem fundamentar o ecoturismo sustentável, que são os seguintes:

- Não deve degradar os recursos naturais;

- Deve possibilitar experiências participativas e esclarecedoras em primeira mão;

- Deve envolver educação entre todas as partes - comunidades locais, governo, organizações não governamentais, indústria e turistas (antes, durante e depois da viagem);

- Deve incentivar um reconhecimento dos valores intrínsecos dos recursos naturais e culturais, por parte de todos os envolvidos;

- Deve implicar aceitação dos recursos tais como são e reconhecer os seus limites, o que pressupõe uma administração voltada para o abastecimento;

- Deve promover a compreensão e as parcerias entre muitos envolvidos, e isso pode incluir o governo, organizações não governamentais, a indústria, os cientistas e a população local (tanto antes como durante as operações);

- Deve promover responsabilidades e um comportamento moral e ético em relação ao meio ambiente natural e cultural, por parte de todos os envolvidos;

- Deve trazer benefícios a longo prazo - para os recursos naturais e culturais, para a comunidade e para as indústrias locais (esses benefícios podem ser de preservação científica, social, cultural ou econômica);

- Deve assegurar que nas operações de ecoturismo, a ética inerente a práticas ambientais responsáveis se aplique não apenas aos recursos externos (naturais e culturais) que atraem turistas, mas também a suas operações internas.

Para AMÂNCIO \& GOMES (2001), discutir ecoturismo e desenvolvimento sustentável é um desafio interessante, principalmente quando se tenta descaracterizar a atividade ecoturística de um estigma elitista. Ver o ecoturismo como uma atividade a ser trabalhada ou "explorada" por grupos 
capitalizados financeiramente é reduzir seu papel como elemento importante para promover o desenvolvimento rural e incluir segmentos da população que são historicamente marginalizados do acesso a mecanismos de produção na sociedade capitalista sejam eles materiais ou de caráter social e cultural.

Para prevenir os impactos ambientais do turismo, a degradação dos recursos e a restrição do seu ciclo de vida, é preciso concentrar os esforços para o desenvolvimento sustentável, não apenas do patrimônio natural, mas também dos produtos que se estruturam sobre os atrativos e equipamentos turísticos.

Segundo RUSCHMANN (1997), os conceitos de turismo sustentável e desenvolvimento sustentável estão intimamente ligados à sustentabilidade do meio ambiente, principalmente nos países menos desenvolvidos. Isto porque o desenvolvimento e o desenvolvimento do turismo em particular dependem da preservação da viabilidade de seus recursos de base. Encontrar o equilíbrio entre os interesses econômicos que o turismo estimula e um desenvolvimento da atividade que preserve o meio ambiente não é tarefa fácil, principalmente porque seu controle depende de critérios e valores subjetivos e de uma política ambiental e turística adequada - que ainda não se encontrou no Brasil e em vários outros países.

O programa Pólos de Ecoturismo é o primeiro inventário do potencial ecoturístico do Brasil. Foi desenvolvido pela Embratur, em parceria com o Instituto de Ecoturismo do Brasil, e levou três anos para ser concluído. Foram identificados 96 pólos de ecoturismo em todo país. Incluindo destinos já existentes, mas com grande potencial para o ecoturismo, e lugares pouco explorados. A superfície territorial brasileira abriga diferentes ecossistemas, destacando-se:

\section{REGIÃO NORTE}

É a maior das regiões brasileiras. Representa $45 \%$ da área do país, e sua população perfaz somente $7 \%$ do total de habitantes. Ao contrário do que se pensa, não é homogênea. Diferentes populações ocupam seu território, 
em meio à cobertura vegetal variada, em agrupamentos humanos que variam desde grandes cidades até as habitações isoladas dos povos ribeirinho e das inúmeras nações indígenas.

As características principais da paisagem são a quantidade e o tamanho da rede hídrica convergindo para a calha do imenso Rio Amazonas, em meio a terrenos cobertos por matas várzeas, de igapó, de terra firme, campinaranas (caatinga) e cerrado, num clima predominantemente quente e úmido.

Ao norte, o relevo marcado por planaltos, chapadas e picos elevados, contrasta com as terras baixas que se estendem até a faixa litorânea, sujeita aos efeitos das marés.

É a área de maior biodiversidade do planeta. Sua fauna e flora exuberantes, a beleza de suas águas, as formações geológicas e a cultura rica e variada dos seus habitantes atraem visitantes do mundo em busca de um contato direto com a natureza.

\section{Os Pólos de Ecoturismo da Região Norte}

Figura 2: Pólos de Ecoturismo da Região Norte.

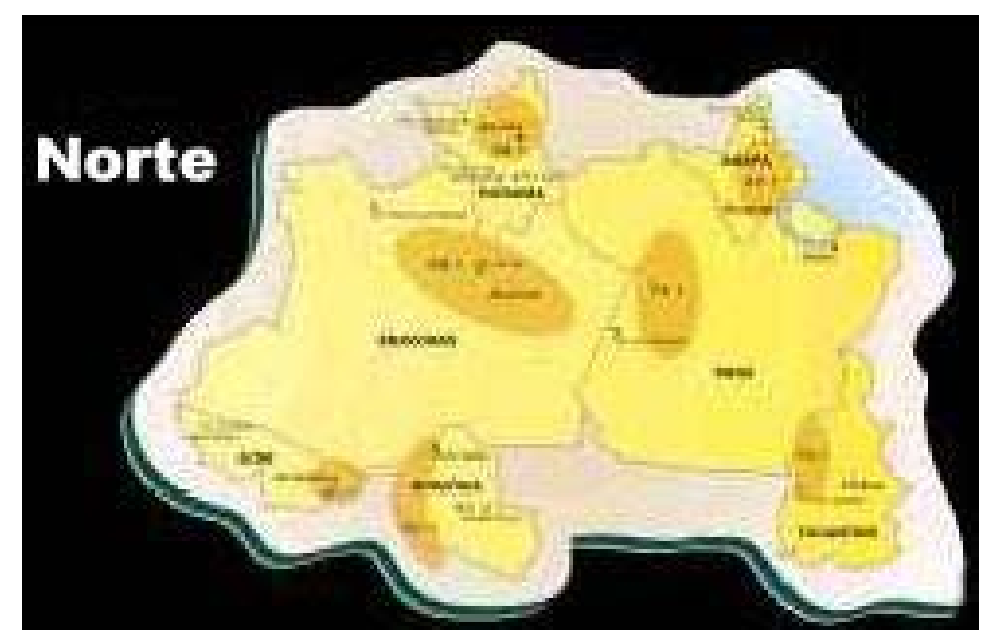

Fonte: http://www.terra-planejamento.com.br/polos/norsu/bahia-ba3.htm 
A AMAZÔNIA, que, historicamente, sempre esteve associada à natureza, constitui-se numa das últimas reservas mundiais de recursos naturais e florestais e um dos ecossistemas mais ricos e preservados do planeta, especialmente por sua Biodiversidade.

Nessa perspectiva, o interesse pelas questões relacionadas à conservação do meio ambiente, confere à AMAZÔNIA um papel de destaque, nos cenários nacional e internacional, por congregar todos os elementos naturais necessários ao sucesso de qualquer programação de ECOTURISMO.

\section{Pólos da Região Norte}

- Estado do ACRE: compreendendo os municípios de Rio Branco, Plácido de Castro, Xapuri e Porto Acre;

- Estado do AMAPÁ: quadrilátero composto pelos municípios de Santana, Macapá, Itaubal, Porto Grande, Amapari, Serra do Navio, Ferreira Gomes, cutias, Tartarugalzinho e Pracuúba;

- Estado do AMAZONAS: integrado pelos municípios de Manaus, Presidente Figueiredo, Barcelos, Novo Airão, Manacapuru, Iranduba, Careiro, Careiro da Várzea, Autazes, Itacoatiara, Silves e Rio Preto da Eva;

- Estado do PARÁ: Tapajós, composto dos municípios de Santarém, Monte Alegre, Óbidos, Alenquer, Oriximiná (margem esquerda do rio amazonas), Belterra e Aveiro (margem do rio tapajós e br-163);

- Estado de RONDÔNIA: compreendendo os municípios de Porto Velho, Guajará Mirim, Vale do Guaporé, tendo como base de apoio o município de costa marques;

- Estado de RORAIMA: abrangendo o norte do estado, integrado pelos municípios de Boa Vista, Amajari, Pacaraima, Uiramutã e Normandia; e

- Estado do TOCANTINS: região da ilha do bananal (municípios de Cazeara e Pium), onde foi criado o parque estadual Côco-Javaés, integrante da área de proteção ambiental ilha do bananal/cantão. 


\section{REGIÃO NORDESTE}

Ocupa pouco mais de $18 \%$ do território nacional e concentra $29 \%$ de sua população.

É coberta por áreas florestais e de cerrado, mas sua maior parte é caraterizada pela caatinga, ambiente semi-árido, onde as chuvas são raras e irregulares e a vegetação adaptada à economia de água.

Porções de mata são encontradas no litoral leste, no limite com a Região Norte e em pontos variados, onde as chuvas são freqüentes e garantem a presença de fontes e rios perenes.

É talvez a região brasileira com maiores contrastes de paisagem e riquezas culturais. Saindo da faixa litorânea, com suas praias, coqueirais e cidades bastantes conhecidas, coberto de formações geológicas, que guardam testemunhos fósseis e inscrições de povos pré-históricos, encontra-se à espera de ser descoberto pelos ecoturistas.

Figura 3: Pólos de Ecoturismo da Região Nordeste.

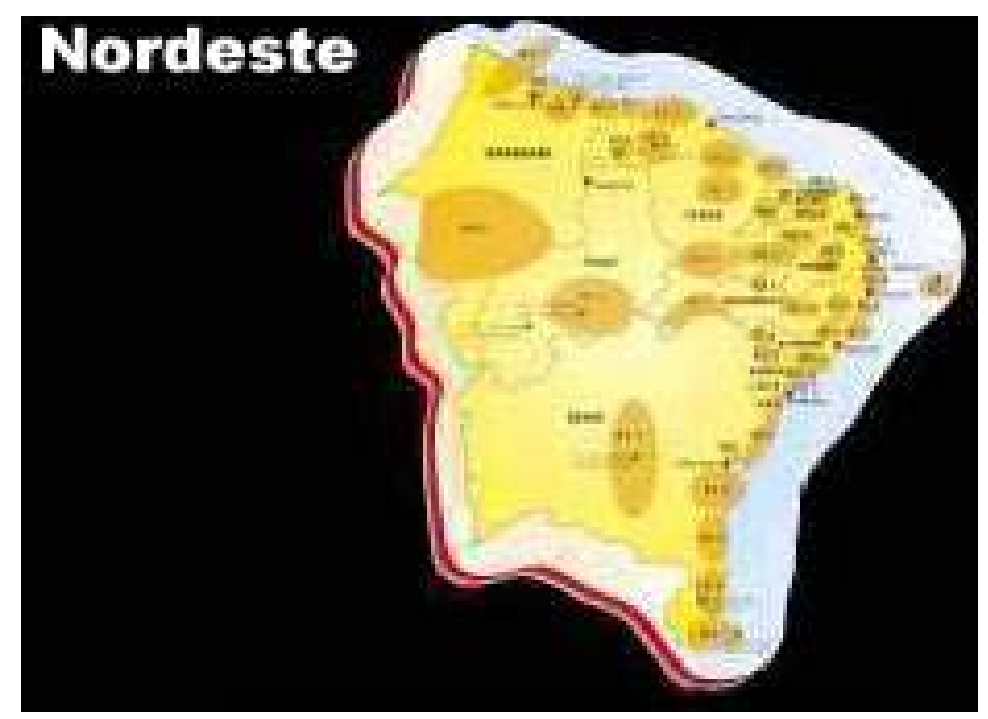

Fonte: http://www.terra-planejamento.com.br/polos/norsu/esanto4.htm 


\section{Maranhão - Principais Atrativos Ecoturísticos}

- Ilhas e Baias na costa

- Bancos de areia, manguezais e restingas

- Espécies raras de fauna

- Formações rochosas submersas

- Praias de areia branca e água limpa

- Conjunto de canais apropriados a navegação e pesca

- Comunidade negra do Quilombo de Frechal

\section{Principais Atrativos Ecoturísticos}

- Arquitetura coloniais, fachadas azulejadas

- Museus

- Igrejas e conventos

- Monumentos, ruínas

- Manifestações folclóricas

- Festas religiosas e populares

- Praias

- Locais de pesca

- Ilhas e rios

- São Luís cidade tombada Patrimônio da Humanidade (Unesco)

- Alcântara cidade tombada Patrimônio Histórico (IPHAN)

\section{Principais Atrativos Ecoturísticos}

- Formações arenosas (lençóis)

- Dunas 
- Manguezais

- Restingas

- Chuvas janeiro a julho, originando lagoas de água doce

- Palmeiras

- Fauna variada

- Parque Nacional

\section{Principais Atrativos Ecoturísticos}

- Vários canais;

- Inúmeras ilhas com praias pouco habitadas;

- Dunas;

- Lagoas na estação chuvosa;

- Vegetação de restinga e manguezal;

- Grande quantidade de aves marinhas.

\section{Principais Atrativos Ecoturísticos}

- Região sul do Maranhão - maior área preservada de cerrado do país;

- Parque estadual do Mirador, proteção a nascentes, fauna e flora;

- Carolina e Imperatriz as margens do rio Tocantins - praias fluviais, pesca, cachoeiras e grutas

\section{Piauí - Principais Atrativos Ecoturísticos}

- Planaltos, chapadas, morros, serras e planícies;

- Cânions

- Fósseis 
- Sítios arqueológicos

- Museu do Homem Americano

- Fauna e flora da caatinga

- Clima entre árido e semi-árido com chuvas de outubro a abril, meses mais quentes

- Parque Nacional

\section{Principais Atrativos Ecoturísticos}

- Afloramentos rochosos muito antigos

- Processos erosivos

- Pinturas rupestres

- Vegetação de zona de transição entre cerrado e caatinga

- Campos inundáveis

- Fauna variada

- Clima quente, chuvas de janeiro a maio

- Parque Nacional

\section{Principais Atrativos Ecoturísticos}

- Vários canais

- Inúmeras ilhas com praias pouco habitadas

- Dunas

- Lagoas na estação chuvosa

- Vegetação de restinga e manguezal

- Muitas aves marinhas 


\section{Principais Atrativos Ecoturísticos}

- Vários canais

- Inúmeras ilhas com praias pouco habitadas

- Dunas

- Lagoas na estação chuvosa

- Vegetação de restinga e manguezal

- Muitas aves marinhas

\section{Principais Atrativos Ecoturísticos}

- Serras, serrotes monolíticos esculpidos por erosão;

- Planície sertaneja com vegetação de caatinga;

- Desenhos e marcas do Homem pré-histórico.

\section{Principais Atrativos Ecoturísticos}

- Ilha úmida do semi-árido;

- Pluviosidade alta;

- Temperaturas amenas;

- Coberturas vegetais com espécies de Mata Atlântica;

- Proximidade do litoral - Fortaleza 100km;

- Fauna diversificada.

\section{Principais Atrativos Ecoturísticos}

- Chapada do Araripe

- Vale do Cariri 


\section{Principais Atrativos Ecoturísticos}

- Topografia notável, formações calcárias;

- Clima ameno;

- Abundância de água para os padrões do nordeste;

- Vegetação de floresta;

- Parque Nacional- grutas escarpas e quedas d'água.

Rio Grande do Norte - Litoral Norte Potiguar - Principais Atrativos Ecoturísticos

- Salinas;

- Baixa precipitação;

- Calor úmido;

- Manguezais dunas e praias pouco freqüentadas;

- Praias protegidas por arrecifes boas para mergulho;

- Falésias;

- Águas límpidas.

Rio Grande do Norte - Litoral Leste - Principais Atrativos Ecoturísticos

- Praias virgens- locais de desova de tartarugas;

- Dunas (Genipabu);

- Lagunas e lagoas;

- Manguezal - população de peixe boi marinho;

- Floresta Atlântica, sítios arqueológicos;

- Construções históricas - Forte do Reis Magos em Natal;

- Parcel das agulhas- coluna rochosa submersa. 
Rio Grande do Norte - Pólo Serras do Sul - Principais Atrativos Ecoturísticos

- Serras graníticas com paisagens e tanques outrora ocupados por fauna pré histórica;

- Pedra da Boca;

- Lagunas e lagoas;

- Monólito da Serra Caiada;

- Sítios arqueológicos;

- Locais para turismo de aventura (rappel, escaladas, etc.)

Rio Grande do Norte - Cabugi - Principais Atrativos Ecoturísticos

- Restos fósseis em morros baixos com inúmeras piscinas naturais escavadas em rochas;

- Casa da Pedra- abrigo de homem pré histórico;

- Pico do Cabugi - único vulcão brasileiro;

- Lagoa Formosa;

- Represa Armando Ribeiro Gonçalves;

Rio Grande do Norte - Seridó - Principais Atrativos Ecoturísticos

- Área serrana;

- Uma das principais províncias arqueológicas do Brasil;

- Açude Gargalheira;

- Museu do Sertanejo;

- Castelo de Pedra;

- Migração de andorinhões para a Serra do Bico das Araras;

- Fauna e flora de caatinga no museu de história natural (IBAMA). 


\section{Rio Grande do Norte - Serras do Sudoeste - Principais Atrativos Ecoturísticos}

- Formações graníticas com muitos sítios arqueológicos;

- Santuário do Lima em Patu;

- Martins - clima ameno, região alta-caverna calcárea - vestígios do homem préhistórico;

- Chapada do Apodi;

- Lajeado de Soledade - abrigos, pinturas fósseis de animais, caverna do Roncador, museu;

- Sitio do Góis - molúsculos fossilizados;

- Felipe Guerra- Cavernas inexploradas, lagos transparentes, carnaíbas.

\section{Paraíba - João Pessoa - Principais Atrativos Ecoturísticos}

- Ponta do Seixas - extremo oriental americano;

- Farol do Cabo Branco;

- Área verde de João Pessoa (Mata Atlântica);

- Praias com piscinas de maré, falésias e arrecifes;

- Praia de Tambada - nudismo;

- Fortaleza de Santa Catarina patrimônio histórico;

\section{Paraíba - Litoral Norte Paraibano - Principais Atrativos Ecoturísticos}

- Rios piscosos;

- Pesca na foz do rio Camaratuba;

- Praias desertas, ondas fortes e coqueirais;

- Barra de Maranguape - preservação do peixe Boi Marinho;

- Baia da traição - ruínas de forte; 


\section{Paraíba - Serra do Borborema - Principais Atrativos Ecoturísticos}

- Rios e vegetação exuberante- caatinga;

- Relevo variado com grutas, blocos de rochas com formas inusitadas, fendas e cachoeiras;

- Pedra do Ingá - inscrições antigas;

- Museu de História Natural- fósseis;

- Açude em meio a caatinga.

\section{Sertão Paraibano - Principais Atrativos Ecoturísticos}

- Picos elevados em meio ao sertão;

- Vegetação de transição entre regiões de altitude e caatinga;

- Sítios arqueológicos;

- Sousa- Pistas de dinossauros na bacia do rio do Peixe;

- Fontes de águas termais;

\section{Pernambuco - Fernando de Noronha - Principais Atrativos Ecoturísticos}

- Relevo vulcânico de aspecto variado;

- Águas límpidas (excelente para mergulhos), fauna variada;

- Piscinas naturais;

- Formações coralinas;

- Aves marinhas;

- Construções antigas;

- Clima quente- limitação de água doce;

Litoral Norte de Pernambuco - Principais Atrativos Ecoturísticos

- Praias com coqueiros excelentes para banhos; 
- Praia de Itamaracá;

- Recife - patrimônio histórico;

\section{Litoral Sul de Pernambuco - Principais Atrativos Ecoturísticos}

- Recifes de coral, águas límpidas excelentes para mergulho;

- Inúmeras praias, elevações graníticas com vista panorâmica- Pedra Grande e da Pimenta;

- Resquícios de Mata Atlântica;

\section{Buique - Principais Atrativos Ecoturísticos}

- Buique - serras areníticas com inscrições rupestres;

- Pesqueira e Venturosa- serras graníticas sítios arqueológicos e local de romeiros;

- Vegetação de caatinga.

\section{Bonito/São Benedito do Sul - Principais Atrativos Ecoturísticos}

- Mata Atlântica;

- Cachoeiras;

- Furna;

- Afloramentos rochosos com bela vista panorâmica;

- Piscinas naturais.

Afogados da Ingazeira / Serra Talhada - Principais Atrativos Ecoturísticos

- Vales e sistema de elevações, paisagens belíssimas em pleno sertão;

- Afloramentos rochosos;

- Piscinas naturais e cachoeiras nas épocas de chuvas; 
- Grutas cavernas, furnas com inscrições rupestres;

- Pico do Papagaio - ponto mais alto de Pernambuco.

Pernambuco - Bacia do São Francisco - Principais Atrativos Ecoturísticos

- Rio São Francisco - paisagem de caatinga;

- Ilhas com praias boas para banho e lagoas pequenas;

- Região produtora de frutas.

Sergipe - Sertão Sergipano do São Francisco - Principais Atrativos Ecoturísticos

- Cânions do São Francisco;

- Ilhas, praias fluviais e cachoeiras;

- Lagos extensos próximos às barragens (Hidrelétrica e Xingó);

- Sítios arqueológicos;

- Relevo ondulado - serras graníticas.

\section{Sergipe - Propriá - Principais Atrativos Ecoturísticos}

- Ilhas fluviais e fluvio marinhas;

- Ilhas, praias fluviais e cachoeiras;

- Pescarias;

- Passeios de barco;

- Foz do rio São Francisco;

- Manguezais e fauna nativa; 


\section{Sergipe - Catinguiba - Principais Atrativos Ecoturísticos}

- Pirambu - praias, várias lagoas, dunas cachoeiras - projeto Tamar, Reserva de Santa Isabel, sítios arqueológicos;

- Gruta da Pedra Furada - construções antigas, museus, manifestações culturais.

\section{Sergipe - Agreste do Itabaiana - Atrativos Ecoturísticos}

- Serras com cachoeiras, poços e córregos ideais para a prática do ecoturismo;

- Trilhas em meio a vegetação diversificada.

\section{Sergipe - Litoral Sul Sergipano - Principais Atrativos Ecoturísticos}

- São Cristão - $4^{a}$ cidade mais antiga do país, tombada como patrimônio da humanidade;

- Foz do rio Real;

- Praias, dunas e coqueirais;

- Mangue seco;

- Passeios de barco;

- Reservas do Castro- Mata Atlântica densa e fechada e manguezais;

\section{Alagoas - Litoral Norte Alagoano - Principais Atrativos Ecoturísticos}

- Na costa- extensa faixa de arrecifes;

- Praias com poucas ondas e piscinas naturais (galés);

- Clima quente, chuvas passageiras;

- Inúmeros rios com cachoeiras e ilhas;

- Lagoas de água doce rodeadas de morros;

- Porções de Mata Atlântica com trilhas para observação de fauna e flora; 
- Lagoas de Mandaú e Manguaba ao sul de Maceió;

\author{
Alagoas - Zona da Mata Alagoana - Principais Atrativos Ecoturísticos \\ - União dos Palmares - cidade histórica- Quilombo dos Palmares; \\ - Chã Preta- Mata Atlântica engenhos antigos - serra (local para vôos de asa \\ delta e paraglaider); \\ - Quebrângulo - serra, Museu do Índio, Museu Graciliano Ramos; \\ - Festas populares;
}

\title{
Alagoas - Zona da Mata Alagoana - Principais Atrativos Ecoturísticos
}

- Lago formado pela construção da barragem do rio São Francisco;

- Praias fluviais;

- Sítios arqueológicos;

- Cachoeiras, cânions;

- Usinas de Xingó e Angiquinho;

- Passeios náuticos;

- Piranhas - cidade histórica;

- Museu do sertão em Piranhas;

- Museu da Ferrovia em Delmiro Gouveia.

\section{Alagoas - Baixo São Francisco - Principais Atrativos Ecoturísticos}

- Penedo - cidade histórica- casario colonial, passeios de barco;

- Foz do rio São Francisco- pororoca, pescaria, passeios de barco. 


\section{Bahia - Chapada Diamantina - Principais Atrativos Ecoturísticos}

- Cidades históricas- Lençóis, Rio de Contas e Igatu;

- Cachoeiras do Sossego, da Fumaça, da Fraga, do Tiburtino, da Primavera;

- Rios e poções;

- Grutas;

- Trilhas e escaladas;

- Parque Nacional da Chapada da Diamantina.

\section{Bahia - Costa dos coqueiros - Principais Atrativos Ecoturísticos}

- Praias com dunas e coqueirais;

- Postos do projeto Tamar- proteção a tartarugas marinhas;

- Castelo Garcia D'Avila;

- Corredeiras- rio Pojuca e Imbassi;

- Piscinas naturais;

- Cachoeiras;

- Vilarejos de pescadores.

Bahia - Baía de Todos os Santos - Principais Atrativos Ecoturísticos

- Centro histórico e cultural, tombado como patrimônio da humanidade;

- Praias;

- Fortes;

- Faróis;

- Parques e passeios pela orla;

- Lagoa do Abaeté; 


\section{Bahia - Costa do Dendê - Principais Atrativos Ecoturísticos}

- Morro de São Paulo - Ilha de Tinharé - praias, ruínas, piscinas naturais, trilhas na mata, farol, passeios de escuna;

- Foz do rio Una - Ilha do Cairu - centro histórico, convento e igreja de Santo Antônio;

- Valença - patrimônio histórico colonial - cachoeiras, rios e matas;

- Baía de Camamu - praias morros e passeios de barcos;

\section{Bahia - Costa do Cacau - Principais Atrativos Ecoturísticos}

- Acervo histórico cultural em Ihéus - igrejas, conventos e museus da época do cacau;

- Fazendas;

- Rios Passeios de barcos;

- Lagoa Encantada, quedas d'água;

- Projeto Mico Leão;

- Águas medicinais da Tororomba;

- Praias, banhos e cavalgadas;

- Reserva do Una - Trilha suspensa em meio à mata.

\section{Bahia - Costa do Descobrimento - Principais Atrativos Ecoturísticos}

- Sítios históricos marco do descobrimento, ruínas, igrejas de Jesuítas;

- Praias, coqueirais, lagoas, locais para caminhadas, mergulho e nudismo (praias desertas);

- Falésias;

- Passeios de barco, observação de fauna marinha em recifes;

- Vilarejo de pescadores e presença de cultura indígena; 
- Parque nacional de Monte Pascoal.

\section{Bahia - Costa das Baleias - Principais Atrativos Ecoturísticos}

- Parque Nacional marinho de Abrolhos - passeios de barco mergulhos observação de baleias;

- Praias;

- Ilhas;

- Manguezais;

- Passeio de barco pelos rios até a ilha da coroa vermelha;

- Foz do rio Mucuri;

- Falésias.

\section{REGIÃO CENTRO-OESTE}

Formada pelos estados de Goiás, do Mato Grosso, Mato Grosso do Sul e pelo Distrito Federal, a Região Centro Oeste destaca-se como uma das maiores macros - regiões do país com 1.607.000,5 km2 de superfície, perfazendo $18,99 \%$ do total nacional. Está localizada na porção central da América do Sul, sendo a única entre as regiões brasileiras que não possui litoral. Limita-se ao norte, com os estados do Pará e Amazonas, a oeste com Rondônia, a Bolívia e o Paraguai, ao sul, com Paraná e São Paulo e a leste, com Minas Gerais, Bahia e Tocantins. É a Segunda maior região brasileira. Ocupa cerca de 19\% do país sendo, porém, a menos povoada, com $7 \%$ da população.

A região se caracteriza, principalmente, por apresentar uma evidente relação de transição entre o Sul - Sudeste, o Nordeste e a Amazônia, notadamente no que se refere aos aspectos físicos de seu território, relevo, clima e vegetação, sua economia, seu povoamento e estágios de desenvolvimento. A 
evidência dessa transitoriedade fica clara quando comparadas as paisagens urbanas das cidades da região localizadas ao norte, menos desenvolvidas, com as cidades ao sul, mais desenvolvidas e sob influência direta do Sudeste, especialmente de São Paulo. Possui grandes propriedades rurais e extensas áreas ainda não ocupadas teve, no entanto, um grande desenvolvimento a partir da construção de Brasília e das estradas de rodagem demandando o interior.

A Região Centro Oeste insere-se no domínio do Planalto Central Brasileiro, em sua porção mais a oeste, drenada, principalmente, pelas Bacias Amazônica e Platina. Caracteriza-se por um relevo com variedade de formações como planaltos, chapadões e depressões ocupadas por bacias hidrográficas. Abriga uma das mais fascinantes paisagens brasileiras, o Pantanal, imensa planície alagável, onde se concentram variadíssimos representantes de nossa fauna e um mosaico de formações vegetais.

No sudeste da região aparecem as superfícies cristalinas com as maiores altitudes, atingindo patamares em torno de $1.200 \mathrm{~m}$ no divisor Tocantins Paranaíba, que se estende desde Anápolis até a Chapada dos Veadeiros, onde se encontra o ponto culminante do Centro Oeste, com $1.691 \mathrm{~m}$. Na parte central de Goiás destacam-se superfícies de rochas cristalinas mais rebaixadas, geralmente com 300 a $600 \mathrm{~m}$ de altitude, e testemunhos bastante conhecidos: Serra Dourada e Serra do Estrondo.

A hidrografia regional apresenta características especiais por abranger os divisores de águas Amazonas - Prata e São Francisco - Tocantins, originando cursos de água de grande volume e importância, com destaque aos rios Paraguai, Paranaíba, Araguaia, Tocantins e Xingu. 
Figura 4: Pólos de Ecoturismo da Região Centro-Oeste

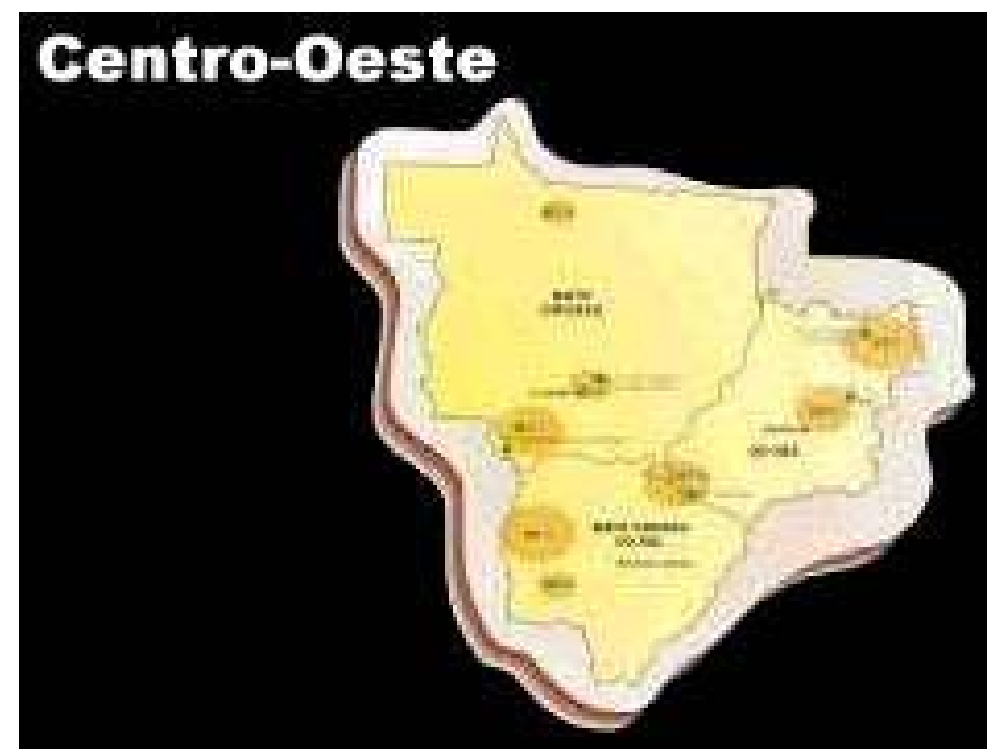

Fonte: Fonte: http://www.terra-planejamento.com.br/polos/norsu/bahia-ba3.htm

\section{Pantanal Sul}

O Pólo Ecoturístico do Pantanal Sul é muito extenso, sendo as atividades ecoturísticas espalhadas por vários pontos da região. Seu elemento agregador é a Estrada Parque, com pousadas e hotéis instalados ao longo do eixo, além dos equipamentos (hotéis e barco - hoteis) nos rios Paraguai, Miranda e Aquidauana.

\section{Serra da Bodoquena}

O Pólo Ecoturístico da Serra da Bodoquena compreende os atrativos naturais de nascentes ao longo da serra e nos contrafortes da vertente do Pantanal.

\section{Pantanal Norte}

O Pólo Ecoturístico do Pantanal Norte está centrado no trecho da Estrada Transpantaneira entre Poconé e Porto Jofre, sendo ligado a Barão de Melgaço pelas baías de Chacororé e Siá Mariana, chegando, também, até Cáceres, às margens do rio Paraguai. 


\section{Chapada dos Guimarães}

O Pólo Ecoturístico de Chapada dos Guimarães compreende a região do Parque Nacional da Chapada dos Guimarães e seu entorno, tendo atrativos desde a parte baixa da Chapada (município de Cuiabá), a sua borda (cachoeiras e mirantes) e o seu interior (rios, grutas e aspectos históricos do garimpo de diamantes)

\section{Amazônia Matogrossense}

O Pólo Ecoturístico da Amazônia Mato-grossense está localizado na fronteira dos estados de Mato Grosso e Pará, em pleno domínio ecológico da Floresta Amazônica, no município de Alta Floresta (MT); inclui os rios Teles Pires e Cristalino.

\section{Chapada dos Veadeiros}

O Pólo Ecoturístico da Chapada dos Veadeiros compreende atividades no Parque Nacional da Chapada dos Veadeiros e em seu entorno, além das áreas de interesse espeleológico nos municípios de São Domingos e Posse.

\section{Pirenópolis}

O Pólo Ecoturístico de Pirenópolis está inserido na Serra dos Pirineus, praticamente eqüidistante de Brasília e Goiânia. Tem como principais atrativos os municípios históricos de Pirenópolis e Corumbá de Goiás com várias cachoeiras e belas paisagens serranas.

\section{Parque Das Emas}

O Pólo Ecoturístico do Parque das Emas compreende a região e seu entorno, com atrativos em Costa Rica (MS) representados por bordas de chapadas e nascentes, em Mineiros por cachoeiras e em Serranópolis por rios 
rápidos e pinturas rupestres.

\section{REGIÃO SUDESTE}

Ocupa apenas $11 \%$ da área do País e concentra quase metade de sua população (42\%). É a região mais desenvolvida economicamente, onde se localizam as três maiores áreas metropolitanas do Brasil, São Paulo, Rio de Janeiro e Belo Horizonte, sem dúvida responsáveis por grandes problemas ambientais e descaracterização da paisagem original. No entanto, ainda conserva áreas protegidas, principalmente no litoral de extrema beleza, ladeado pela exuberante Floresta Atlântica, assim como no interior, marcado por serras, cachoeiras, rios e reservatórios.

Por outro lado, os inúmeros testemunhos da história e da ocupação humana desde o descobrimento até os dias atuais, somam-se aos atrativos naturais, constituindo um patrimônio valioso para prática do ecoturismo.

Figura 5: Pólos de Ecoturismo da Região Sudeste

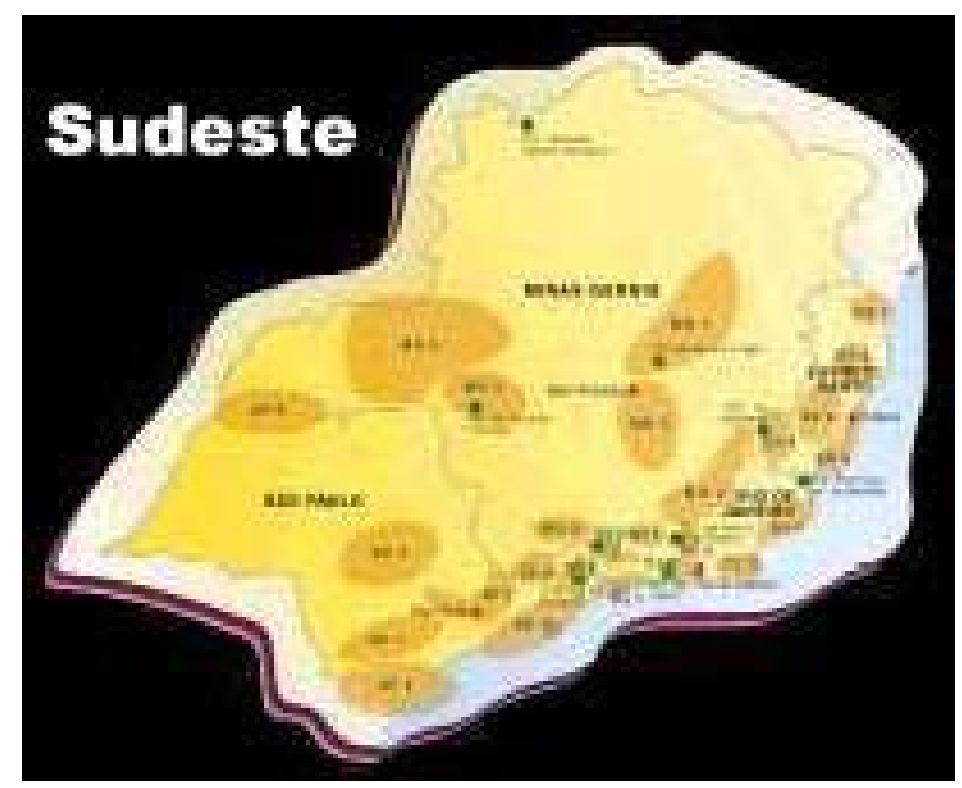

Fonte: http://www.terra-planejamento.com.br/polos/norsu/bahia-ba3.htm 


\section{Minas Gerais - Pólo das Grutas - Principais Atrativos Ecoturísticos}

- Região de Juiz de Fora;

- Região montanhosa, vegetação de Mata Atlântica, clima ameno;

- Atrativos históricos culturais;

- Praticas ecoturísticas- canyoning, off road, passeios a cavalo, canoagem, escaladas;.

- Parque Nacional da Caparaó;

- Parque Estadual do Ibitipoca.

\section{Minas Gerais - Zona da Mata - Principais Atrativos Ecoturísticos}

- Região de Ouro Preto;

- Museus parques, mirantes e cachoeiras;

- Atrativos históricos culturais - obras de Aleijadinho e Ataide;

- Praticas ecoturísticas;

- Parque natural do Caraça;

- Parque Estadual do Itacolomi.

Minas Gerais - Circuito do Ouro - Principais Atrativos Ecoturísticos

- Região Ouro Preto;

- Museus, parques, mirantes e cachoeiras;

- Praticas ecoturísticas;

- Parque Natural do Caraça;

- Parque Estadual do Itacolomi. 


\section{Minas Gerais - Terras Altas da Mantiqueira - Principais Atrativos}

\section{Ecoturísticos}

- Região Itamonte;

- Fica entre os 7 picos mais altos do país, região rica em fauna e flora com cachoeiras;

- Praticas ecoturísticas;

- Parque Nacional do Itatiaia.

\section{Minas Gerais - Canastra - Principais Atrativos Ecoturísticos}

- Região de São Roque de Minas;

- Praticas ecoturísticas;

- Parque Nacional da Serra da Canastra;

\section{Minas Gerais - Caminhos do Cerrado - Principais Atrativos Ecoturísticos}

- Região Araxá;

- Grutas e cachoeiras propícios para canoagem;

- Atrativos históricos culturais;

- Termas de Araxá, banhos terapêuticos.

\section{Espírito Santo - Pólo Itaúnas - Principais Atrativos Ecoturísticos}

- Região de Conceição da Barra;

- Rios, alagados, lagoas e manguezais;

- Parque Estadual de Itaúnas;

- Projeto Tamar;

- Reserva biológica Córrego Grande e Córrego do Veado;

- Floresta Nacional Rio Preto. 


\section{Espírito Santo - Delta do Rio Doce - Principais Atrativos Ecoturísticos}

- Região de Linhares;

- Praias arborizadas, fontes de água mineral, lagoas ilhas, grandes manguezais;

- Lagoa Juparanã;

- Reserva de Comboios- Projeto Tamar;

- Praia da Barra Seca- praia oficial de nudismo;

- Reserva do Vale do Rio Doce;

- Reserva Biológica de Sooterama.

\section{Espírito Santo - Passos de Anchieta - Principais Atrativos Ecoturísticos}

- Região Guarapari;

- Parque estaduais e municipais;

- Atrativos históricos culturais;

- Práticas ecoturísticas;

- Município de Anchieta - onde viveu e morreu o Padre Anchieta;

- Passos de Anchieta- trilha de $90 \mathrm{~km}$ pelo litoral que pode ser feita a pé, de bicicleta, a cavalo ou pelo mar.

\section{Espírito Santo - Serras Capixabas - Principais Atrativos Ecoturísticos}

- Região de Domingos Martins conhecida como região Serrana;

- Clima frio, colonização européia, montanhas, reservas florestais;

- Atrativos históricos culturais;

- Práticas ecoturísticas;

- Museu de Biologia Melo Leitão;

- Parque Nacional do Caparaó; 
- Parque Estadual Pedra Azul;

- Reserva Kautsky, acesso só com autorização paraíso para biólogos e ecoturistas.

\section{Espírito Santo - Caranapaó - Principais Atrativos Ecoturísticos}

- Região Dores do Rio Preto;

- Cachoeiras, mirantes, montanhas;

- Parque Nacional do Caparaó;

- Parque estadual cachoeira da Fumaça (144m).

Rio de Janeiro - Costa Verde - Principais Atrativos Ecoturísticos

- Região de Parati;

- Atrativos históricos culturais- construções do século XVII e XVIII;

- Vegetação de Mata Atlântica, praias, ilhas reservas ecológicas;

- Práticas ecoturísticas;

- Parque Nacional da Serra da Bocaina.

Rio de Janeiro - Itatiaia - Principais Atrativos Ecoturísticos

- Região de Visconde de Mauá;

- Práticas ecoturísticas;

- Parque Nacional de Itatiaia - situado na Serra da Mantiqueira - cachoeiras, lagos, rios, penhascos;

Rio de Janeiro - Rio/Niterói - Principais Atrativos Ecoturísticos

- Região do Grande Rio;

- Morros - Pão de Açúcar, Corcovado, áreas de proteção ambiental (restinga da 
Marambaia),lagoas trechos de Mata Atlântica primária;

- Práticas ecoturísticas;

- Município do Rio de Janeiro - patrimônio histórico, belezas naturais;

- Município de Niterói - Fortaleza de Santa Cruz de 1555, museus ruínas, praias e ilhas.

\section{Rio de Janeiro - Região Serrana - Principais Atrativos Ecoturísticos}

- Região de Petrópolis e Teresópolis;

- Atrativos históricos culturais;

- Práticas ecoturísticas;

- Parque Nacional da Serra dos Órgãos- pico Dedo de Deus, Pedra do Sino, piscinas naturais, cachoeiras e trilhas.

\section{Rio de Janeiro - Região dos Lagos - Principais Atrativos Ecoturísticos}

- Região de Búzios e Cabo Frio;

- Praias, restingas, grutas, cascatas e lagoas (lagoa de Araruama);

- Práticas ecoturísticas.

Rio de Janeiro - Vale do Paraíba - Principais Atrativos Ecoturísticos

- Região de Conservatória;

- Atrativos históricos culturais- Museus, antigas fazendas, casarões dos barões do café.

Rio de Janeiro - Costa Doce - Principais Atrativos Ecoturísticos

- Região de Macaé;

- Praias paradisíacas algumas com areias medicinais; 
- Parque Nacional de Jurubatiba - guarda características da época que os portugueses chegaram ao Brasil.

\section{São Paulo - Alto do Paranapanema - Principais Atrativos Ecoturísticos}

- Vegetação de mata e cerrado com rios corredeiras, cachoeiras, cânions, cascatas e cavernas;

- Atrativos históricos culturais- Museu dos Jesuítas do Embu, Templo Budista em Itapecirica da Serra;

- Práticas ecoturísticas;

- Parque Estadual Intervales na Serra de Paranapanema com Mata Atlântica primária.

\section{São Paulo - Serras Paulistas - Principais Atrativos Ecoturísticos}

- Região de Brotas;

- Faixas de cerrado, de Mata Atlântica, morros, cascatas;

- Atrativos históricos culturais - antigos casarões e fábricas tombados pelo IPHAN

- Práticas ecoturísticas;

- Mata da Câmara no município de São Roque é considerada patrimônio da humanidade.

\section{São Paulo - Região das Cuestas - Principais Atrativos Ecoturísticos}

- Região de Brotas;

- Cachoeiras quedas d'água trilhas e grutas;

- Atrativos históricos culturais- museus engenhos e igrejas;

- Práticas ecoturísticas;

- Areia que canta; 
- Parque ecológico de São Carlos.

\section{São Paulo - Vale Ribeira do Iguape - Principais Atrativos Ecoturísticos}

- Região de Registro;

- Cavernas, abismos com vestígios de animais pré-históricos, cacheiras, corredeiras, piscinas naturais;

- Atrativos históricos culturais- arquitetura colonial, museus e ruínas;

- Parque Estadual Turístico do Alto Ribeira (PETAR) - concentração de cavernas;

- Práticas ecoturísticas;

- Caverna do Diabo - a maior do país;

- Pólo ecoturístico do Lagamar - região de Cananéia, Iguapé, Ilha Comprida e Pariqueira Açu;

- Parque Estadual da llha do Cardoso-90\% coberta por Mata Atlântica.

\section{São Paulo - Paraíba do Sul - Principais Atrativos Ecoturísticos}

- Região de São José do Barreiro;

- Cachoeiras, corredeiras, piscinas naturais, vegetação de Mata Atlântica;

- Atrativos históricos culturais- Igrejas, antigas fazendas de café tombadas, casario colonial do século XVIII e XIX em São Luiz do Paraitinga;

- Práticas ecoturísticas;

- Parque Nacional da Serra da Bocaina;

- Parque Estadual da Serra do Mar - trilhas e cachoeiras;

- Parque Estadual da llha do Cardoso-90\% coberta por Mata Atlântica; 


\section{São Paulo - Mantiqueira - Principais Atrativos Ecoturísticos}

- Região de Campos de Jordão;

- Estância hidromineral e climática, clima excelente;

- Atrativos históricos culturais- museus, mosteiros, palácios, igrejas, estações ferroviárias;

- Práticas ecoturísticas;

- Parque ecoturístico da Pedra do Baú;

- Horto Florestal ou Parque Estadual- maior reserva de coníferas do país;

- Morro do Elefante $1800 \mathrm{~m}$.

\section{São Paulo - Litoral Paulista - Principais Atrativos Ecoturísticos}

- Estações balneárias com praias corredeiras, Mata Atlântica, reservas indígenas, manguezais;

- Juréia-Itatins em Peruíbe- flora riquíssima;

- Atrativos históricos culturais- casario colonial de São Sebastião, centro histórica de Santos, Ubatuba, Caraguatatuba, aquários, museus fortalezas;

- Práticas ecoturísticas;

- Parque Estadual Marinho da Laje de Santos;

- Parque Estadual da Serra do Mar;

- Parque Estadual de Ilha Bela;

- Parque Estadual da Ilha Anchieta.

\section{São Paulo - Grandes Lagos - Principais Atrativos Ecoturísticos}

- Região de São José do Rio Preto;

- Vegetação de cerrado e capoeira;

- Atrativos históricos culturais- centro cultural Daud Jorge Simão em São José 
do Rio Preto;

- Práticas ecoturísticas;

- Trilha ecológica da Mata dos Macacos.

\section{REGIÃO SUL}

A Região Sul, formada pelos estados do Paraná, Santa Catarina e Rio Grande do Sul, é a menor das regiões brasileiras, com uma superfície de $577.214 \mathrm{~km} 2$, que eqüivale a apenas $6,76 \%$ do total nacional. Limita-se, ao norte, com os estados de São Paulo e Mato Grosso do Sul, a oeste com o Paraguai e a Argentina e, ao sul, com o Uruguai. A leste, numa extensão de $1.350 \mathrm{~km}$, é banhada pelo Oceano Atlântico. Está compreendida, aproximadamente, entre os paralelos $22^{\circ} 30^{\prime}$ e $51^{\circ} 30^{\prime}$ sul e os meridianos $48^{\circ} 00^{\prime}$ e $57^{\circ} 30^{\prime}$ oeste, praticamente na Zona Subtropical, cortada pelo Trópico de Capricórnio na altura da cidade de Maringá - PR.

Com 23.516.730 habitantes, a Região Sul apresenta o terceiro maior contingente populacional do País, participando com $15 \%$ do total. É a menor das regiões brasileiras, ocupando $7 \%$ do território nacional. Na Região Sul, a Bacia Hidrográfica do Paraná ocupa uma área de 196.564 km2, representada por um pequeno segmento do volumoso rio Paraná que se estende da foz do rio Paranapanema até a foz do rio Iguaçu, apresentando-se consideravelmente largo a montante da cidade de Guaíra (PR), onde supera 2,5 km de largura. Apesar de sua pouca extensão na região, o Rio Paraná apresenta uma importante rede de afluentes, tanto sob o ponto de vista dos aspectos hídricos, como energéticos e de aproveitamento turístico. Além do Rio Paraná, destacam-se nessa bacia, os rios Paranapanema, Iguaçu, Tibagi, Itararé, das Cinzas e Pirapó.

Ocupando 178.235 km2, a Bacia Hidrográfica do Rio Uruguai está representada no sul pelo rio do mesmo nome, seus formadores e afluentes, abrangendo uma área que se estende até a confluência com o rio Quaraí, na fronteira do Brasil com o Uruguai.

A paisagem originalmente marcada por florestas, mescladas aos campos interiores e formações litorâneas, foi bastante modificada pela 
implantação de agricultura intensiva e pelos costumes dos diferentes povos colonizadores. Pouco resta da cobertura vegetal primitiva, substituída por culturas características das regiões temperadas. Suas pequenas propriedades, a arquitetura típica de suas cidades, as manifestações culturais, imprimem a toda a região uma fisionomia diferente, um ar europeu.

Apesar dessas interferências, o Sul ainda guarda porções representativas do ambientes naturais, como serras, cânions, picos elevados, litoral com as mais variadas formações e, sobretudo, as inigualáveis Cataratas do Iguaçú.

A Região Sul apresenta índices consideráveis em relação ao turismo nacional. Dados apresentados pela EMBRATUR (1992 a 1994) mostram que $50 \%$ das oito cidades mais visitadas do país são sulinas: Florianópolis, Foz do Iguaçu, Porto Alegre e Camboriú.

Figura 6: Pólos de Ecoturismo da Região Sul

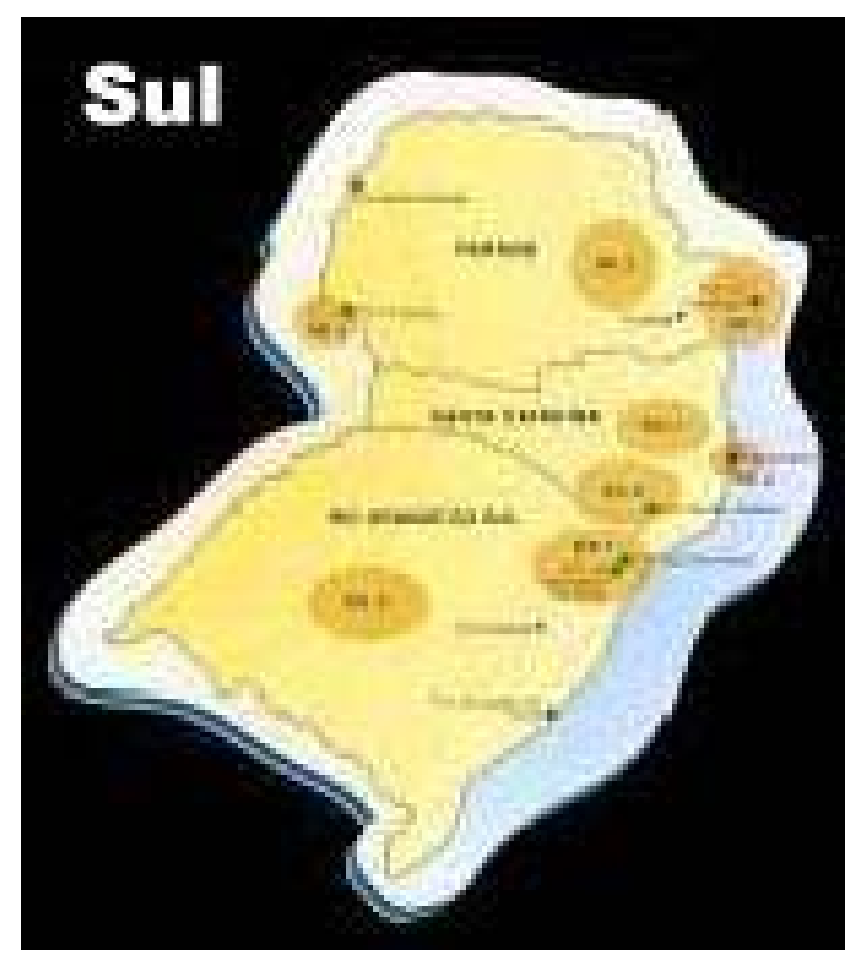

Fonte: http://www.terra-planejamento.com.br/polos/norsu/bahia-ba3.htm 


\section{Paranaguá/Graciosa}

Tendo como unidade formadora o Complexo Estuarino Lagunar de Paranguá/Guaraqueçaba e o Parque Estadual do Marumbi, esse Pólo contempla atividades desde o alto da serra até os limites externos das ilhas de Superagui e do Mel.

\section{Campos Gerais}

Situado na zona de transição entre o Primeiro e Segundo Planalto Paranaense, o Pólo Ecoturístico Campos Gerais tem como unidades formadoras os Parques Estaduais de Vila Velha e Guartelá, seu eixo de ligação e as áreas de entorno.

\section{Costa Oeste}

Localizado nas fronteiras entre Brasil, Paraguai e Argentina, 0 Pólo Ecoturístico Costa Oeste é formado por parte do Reservatório da Represa de Itaipu e seu entorno, tendo como vértices os Parques Nacionais de Iguaçú e o município de Itaipulândia

\section{SANTA CATARINA}

\section{Alto Vale do Itajaí}

O Pólo Ecoturístico do Alto Vale do Itajaí está localizado praticamente no vértice do vale, na confluência dos rios Itajaí do Norte e Itajaí Açu. Propicia a prática de esportes radicais como rafting, rappel, escalada, em várias cachoeiras e observação em áreas de natureza ainda preservada.

\section{Ilha de Santa Catarina}

O Pólo Ecoturístico Ilha de Santa Catarina tem como unidade formadora o alinhamento das Unidades de Conservação existentes no município de Florianópolis e seu entorno. É limitado ao sul pelo Parque Estadual Serra do 
Tabuleiro, ao norte pela Reserva Biológica do Arvoredo e a noroeste pela APA de Anhatomirim.

\section{Planalto Serrano}

Os elementos que formam o Pólo Ecoturístico Planalto Serrano são: a região de Lages com suas estruturas voltadas ao turismo rural, o Parque Nacional de São Joaquim e as serras adjacentes.

\section{RIO GRANDE DO SUL}

\section{Serra Gaúcha}

O Pólo Ecoturístico Serra Gaúcha compreende a região desde o complexo turístico Canela/Gramado até os Parques Nacionais de Aparados da Serra e da Serra Geral.

\section{Região Central}

O Pólo Ecoturístico da Região Central está inserido na área da transição entre os terrenos altos do final da Serra Geral e as terras baixas e planas do Pampa Gaúcho. 


\section{CONSIDERAÇÕES FINAIS}

O presente trabalho fez uma análise da questão ambiental destacando seus acontecimentos marcantes, relatou a evolução do turismo buscando analisar a evolução e proposta de desenvolvimento sustentável através do ecoturismo no Brasil, já que o mesmo tem o objetivo de incentivar a conservação e a utilização harmoniosa do patrimônio natural e cultural, além de estimular a geração de renda e a qualidade de vida das populações envolvidas. Nesse processo é estabelecido um vínculo evidente entre benefício recebido e proteção dos recursos, assegurando que a atuação da população não se reverta em impacto negativo. Cooperando com o bem estar das comunidades locais. Esta é talvez a característica mais importante do ecoturismo. A atividade ecoturística deve valorizar ao máximo as comunidades locais de entorno de alguma região com atributos ecoturísticos.

Espera-se que este levantamento inicial de dados possa representar uma nova perspectiva para realização de trabalhos nessa área, proporcionando conhecimento científico no setor ecoturístico. Não obstante, o fato de que o ecoturismo é um meio de se obter o desenvolvimento sustentável e consequentemente contribuir para o desenvolvimento sócio-econômico, representando um gerador de emprego e renda, além de beneficiar as populações envolvidas. Para os ecoturistas é muito importante o nível de envolvimento da comunidade local nas atividades ligadas à sua visita.

O governo tem contribuído para criação de um clima oficial favorável ao ecoturismo. Como exemplos, na Bahia a Secretaria de Turismo promove locais como a Chapada da Diamantina - extensão de quase 40 mil $\mathrm{Km}^{2}$, rodeada pela caatinga nordestina, onde se multiplicam bromélias, orquídeas e sempre-vivas. No Maranhão, o Parque Nacional dos Lençóis e o Delta do Parnaíba são as meninas-dos-olhos do Plano de Desenvolvimento Integral do Turismo do Estado.

Mas foi Mato Grosso do Sul que mais contribuiu para o incentivo 
do crescimento do ecoturismo, lá foi implantado o ICMS ecológico (incentivo aos municípios com maior área de preservação). Há quatro anos, havia apenas 137 hectares preservados. Hoje, há oito parques demarcados, que somam mais de 300 mil hectares preservados. Estão previstas obras de infra-estrutura e de melhoria na qualidade das águas das Bacias de Bonito ( MS ), além da pavimentação da estrada Bonito-Bodoquena e a viabilização do Aeroporto de Bonito.

Conclui-se que o ecoturismo é uma modalidade do turismo de crescimento acentuado, podendo se transformar numa solução para a degradação do meio ambiente, aliado ao interesse por questões ambientais, sociais e culturais. No Brasil, o ecoturismo ainda é insustentável, entretanto com ajuda do governo, ONG's e órgãos competentes, este quadro pode mudar, criando planejamentos adequados, regulamentando e incentivando o ecoturismo, conscientizando empresários, investidores e a comunidade envolvida sobre a exploração e conservação, assim, tornar-se-á ecologicamente sustentável, promovendo, estabilidade econômica, promoção social e desenvolvimento nacional. São necessários estudos voltados para analisar os problemas de infraestruturas que dificultam a implantação do setor no Brasil, analisar a oferta e a demanda turística, além de conhecer os produtos turísticos e informações referentes ao potencial do nosso meio ambiente para desencadear projetos na área ecológica. A sociedade almeja e considera que a atividade turística deve ser praticada com organização, objetivos e estratégias bem definidas. A preocupação verdadeira com a infra-estrutura, de forma a se tornar um instrumento do desenvolvimento local sustentado, garantirá a melhoria da qualidade de vida e a preservação do meio ambiente. 


\section{BIBLIOGRAFIA}

AMÂNCIO, R. \& GOMES, M. A. O. Ecoturismo e sustentabilidade. Curso de Pós Graduação "Lato Senso" (Especialização) à distância - Ecoturismo: Interpretação e educação ambiental. Lavras: UFLA/FAEPE, 2001.

CEBALLOS-LASCURÁIN- in LINDBERG, K e D. Hawkins - Ecoturismo - um Guia para Planejamento e Gerenciamento e Gestão- Editora SENAC, 1995.

NOVAES, Marlene Huebes. O turismo no espaço rural de Joinville, S. C. na ótica do planejamento. In: CONGRESSO BRASILEIRO DE TURISMO RURAL: turismo no espaço rural brasileiro, 1, 1999, Piracicaba. Anais... Piracicaba: Fealq, 1999. p. 193 - 199

RUSCHMANN, D. V. M. Turismo e planejamento sustentável: A proteção do meio ambiente. Campinas: Papirus, 1997. 6.ed. 199p.

SWARBROOKE, J. turismo sustentável: turismo cultural, ecoturismo e ética, vol. 5 - São Paulo: Aleph, 2000.

WESTERN, David. Definindo ecoturismo. In: LINDBERG, Kreg. HAWKINS, E. Donald editores) Ecoturismo: um guia para planejamento e gestão. São Paulo: Senac, 1999. 2. ed. P. 13 - 22.

Lindberg \& Hankins, 1995)

(CRESPO, 1998)

Ângelo-Furlan (1996) (CMMAD, 1998, p. 53 apud Figueiredo, 1999:83)

Trigo (1995)

Faria, Dóris Santos de. e Kátia Saraiva de Carneiro. Sustentabilidade ecológica no turismo. - Brasília: Editora Universidade de Brasília, 2001. 96p. (p 12, 13, 14, 69)

DIAS, G. Freire . Educação ambiental: Princípios e práticas. - Editora Gaia. SP. 1992. (p. 67). 
SIMÕES, M.do Socorro. Memória e Comunidade entre o Rio e a Floresta. Belém: UFPA,2000.

Coriolano, Luzia N. Debates ecológicos. Fortaleza: UEC, 2001.

AULICENO, Madalena Pedroso, "Algumas implicações da exploração turística dos recursos naturais" in RODRIGUES, Adry Balastreri (org.) Turismo e Ambiente: Reflexões e Propostas, São Paulo: Editora Hucitec, 1997.

AMÂNCIO, R. \& GOMES, M. A. O. Ecoturismo e sustentabilidade. Curso de Pós Graduação "Lato Sensu" (Especialização) à distância - Ecoturismo: Interpretação e educação ambiental. Lavras: UFLA/FAEPE, 2001.

BARRETO, Margarita, Manual de Iniciação ao Estudo do Turismo, Campinas São Paulo: Papirus, 1995 (Coleção Turismo).

BRASIL, Diretrizes para uma política nacional de ecoturismo/Coordenação de Silvio Magalhães Barros e Denise Hamú M. de La Penha. Brasília: EMBRATUR, 1994.

CEPEDA, Renan. "Turismo no Brasil - Um negócio para profissionais". Revista Rumos - Economia \& Desenvolvimento para os novos tempos, edição de fevereiro de 2000, págs. 34-38.

CMMAD/Comissão Mundial sobre Meio Ambiente e Desenvolvimento - Nosso Futuro Comum $-2^{\circ}$ ed. - Rio de Janeiro: Editora da Fundação Getúlio Vargas, 1991.

COELHO, Maria Célia Nunes, "Reflexões sobre Ecoturismo na Amazônia", in FIGUEIREDO, Silvio Lima (org.). O Ecoturismo e a Questão Ambiental na Amazônia, Belém: UFPA/NAEA, 1999.

CONTI, José Bueno, "A natureza nos caminhos do turismo" in RODRIGUES, Adry Balastreri (org.) Turismo e Ambiente: Reflexões e Propostas, São Paulo: Editora Hucitec, 1997.

CRESPO, Samyra, "Desenvolvimento Sustentável: as ONGS devem se engajar na elaboração das Agendas 21", Proposta - Revista Trimestral de Debate da Fase. Ano 27 n. ${ }^{\circ} 77$, editora FASE, junho/agosto, 1998.

FIGUEIREDO, Luiz Afonso Vaz de, "Ecoturismo e participação popular no Manejo 
de áreas protegidas: aspectos conceituais, educativos e reflexões", in RODRIGUES, Adry Balastreri (org.) Turismo e Ambiente: Reflexões e Propostas, São Paulo: Editora Hucitec, 1997.

GOIÁS, FEMAGO - Fundação Estadual do Meio Ambiente de Goiás. Araguaia Resgatar a sua integridade, Femago, Goiânia, Sd.

LAGE, Beatriz Helena Gelas \& MILONE, Paulo Cesar (orgs.), Turismo - Teoria e Prática, São Paulo: Editora Atlas, 2000.

LEMOS, Amália Inês Geraigesde, org. Turismo: Impactos sócio-ambiente, Hucitec, São Paulo, 1996.

LEROY, Jean Pierre \& MAIA, Kátia Drager \& GUIMARÃES, Roberto Pereira (orgs.) BRASIL SÉCULO XXI: Os Caminhos da Sustentabilidade Cinco Anos depois da Rio 92. Fórum Brasileiro de ONG's e Movimentos Sociais para o Meio Ambiente e Desenvolvimento, Rio de Janeiro, FASE, 1997.

LINDBERG, Kreg. \& HANKINS, Donal E. (editores) Ecoturismo: Um guia para planejamento e gestão. prefácio de David Western. Tradução de Leila Cristina de M. Darin, revisão técnica de Oliver Hillel - São Paulo, Editora SENAC, São Paulo, 1995.

MACHADO, Ewerton Vieira, "Turismo, paisagem e ambiente: 0 viés do desenvolvimento sustentável - algumas notas como contribuição ao debate", in RODRIGUES, Adry Balastreri (org.) Turismo e Ambiente: Reflexões e Propostas, São Paulo: Editora Hucitec, 1997.

NOVAES, Marlene Huebes. O turismo no espaço rural de Joinville, S. C. na ótica do planejamento. In: CONGRESSO BRASILEIRO DE TURISMO RURAL: turismo no espaço rural brasileiro, 1, 1999, Piracicaba. Anais... Piracicaba: Fealq, 1999. p. 193 - 199 RUSCHMANN, D. V. M. Turismo e planejamento sustentável: A proteção do meio ambiente. Campinas: Papirus, 1997. 6.ed. 199p.

ROCHA, Genylton Odilon Rêgo da., "Ecoturismo na Amazônia: Uma análise das políticas públicas planejadas pela SUDAM", in RODRIGUES, Adry Balastreri (org.) Turismo e Ambiente: Reflexões e Propostas, São Paulo: Editora Hucitec, 1997. 
RUSCHMANN, Doris Van de Meene, "Planejamento e ocupação do território através da expansão da atividade turística: Condicionamentos básicos a partir da questão ambiental", in RODRIGUES, Adry Balastreri (org.) Turismo e Ambiente: Reflexões e Propostas, São Paulo: Editora Hucitec, 1997.

SACHS, Ignacy, 1993, Estratégias de Transição para o Século XXI: desenvolvimento e meio ambiente tradução Magda Lopes - São Paulo: Studi Nobel: Fundação do desenvolvimento administrativo, 1993.

SANTOS, Selene Herculano dos., Reflexões Críticas...(sd. sc).

TRIGO, Luiz Gonzaga Godoi, "Turismo e Desenvolvimento Sustentável”, in FIGUEIREDO, Silvio Lima (org.). O Ecoturismo e a Questão Ambiental na Amazônia, Belém: UFPA/NAEA, 1999.

TRIGO, Luiz Gonzaga Godoi, Turismo Básico, Série Apontamentos, São Paulo: Editora SENAC, 1995.

SWARBROOKE, J. turismo sustentável: turismo cultural, ecoturismo e ética, vol. 5 - São Paulo: Aleph, 2000.

WESTERN, David. Definindo ecoturismo. In: LINDBERG, Kreg. HAWKINS, E. Donald.editores) Ecoturismo: um guia para planejamento e gestão. São Paulo: Senac, 1999. 2. ed. P. 13 - 22.

WIEDMANN, Sônia M. P., "As reservas particulares do patrimônio natural”, in RODRIGUES, Adry Balastreri (org.) Turismo e Ambiente: Reflexões e Propostas, São Paulo: Editora Hucitec, 1997.

\section{OUTRAS FONTES}

EMBRATUR, (www.embratur.gov.br)

Folha do Meio Ambiente, 10 anos, Ano 10, n. ${ }^{\circ}$ 96, agosto de 1999, Uma Publicação da Cultura Viva, Editora Ltda, págs. 20 e 23. Brasília-DF.

Folha do Meio Ambiente, 10 anos, n. 100, dezembro de 1999, Uma Publicação da Cultura Viva, Editora Ltda, pag. 05. Brasília-DF. 
Folha do Meio Ambiente, Ano 11, n. ${ }^{\circ}$ 101, janeiro/fevereiro de 2000, Uma Publicação da Cultura Viva, Editora Ltda, págs. 22 e 23. Brasília-DF. MINISTÉRIO DO MEIO AMBIENTE, (www.mma.gov.br) 
